\title{
A time series assessment of planktonic archaeal variability in the Santa Barbara Channel
}

\author{
A. E. Murray, A. Blakis, R. Massana, S. Strawzewski, U. Passow, A. Alldredge, \\ E. F. DeLong*
}

Marine Science Institute, University of California, Santa Barbara, California 93106, USA

\begin{abstract}
Although detailed temporal studies of marine planktonic cyanobacteria have been reported, relatively little is known about variation of other marine picoplankton groups on time scales on the order of months to years. In this study, we followed variation in relative abundance of planktonic archaeal rRNA at 5 depths in the upper $300 \mathrm{~m}$ of the Santa Barbara Channel (SBC) over $32 \mathrm{mo}$. Small subunit rRNA targeted oligonucleotide probes were used to quantify archaeal, bacterial, and eucaryal rRNA relative abundance. Archaea subgroups were quantified using probes specific to 2 planktonic archaeal groups, termed GI and GII. The archaeal rRNA signal in the upper $20 \mathrm{~m}$ was characterized by intermittent 'blooms' that coincided with increases in the relative abundance of GII rRNA as well as decreases in chlorophyll a (chl a). At greater depths, archaeal rRNA abundance was consistently elevated, approaching bacterial rRNA abundance. The GI rRNA accounted for the majority of the deeper archaeal rRNA signa] throughout the time series. Consistent with a previous report, the 2 groups of archaea had maximal IRNA abundance at different depths. The majority of the variability in the GI archaeal signal in the upper $75 \mathrm{~m}(77 \%)$ could be attributed to a positive relationship with nutrients and negative relationships with prokaryotic abundance, chl $a$, and temperature; although, at most, $41 \%$ of the variability at each depth could be explained. OnIy $21 \%$ of the variability in the GII rRNA signal could be explained by the variables included in the model. Leucine incorporation rates and, to a lesser extent, prokaryote abundance, were highly correlated with chl a and POC levels. Only weak relationships were observed between prokaryote abundance or leucine incorporation and increases in temperature. The results of linear regressions between prokaryote abundance and leucine incorporation suggest that top-down ecological controls may regulate prokaryotic assemblages in this dynamic coastal system. The distribution of the 2 archaeal groups suggested that they responded independently to environmental conditions, are physiologically different, and likely participate in different environmental processes.
\end{abstract}

KEY WORDS: Planktonic archaea - Bacterioplankton ecology - Small subunit rRNA - Santa Barbara Channel

\section{INTRODUCTION}

There are few detailed studies on the spatial and temporal variability of specific prokaryotic picoplankton, yet these are fundamental aspects of their biology and ecology. These microorganisms can constitute up to $50 \%$ of carbon biomass in the upper ocean (Cole et al. 1988). That estimate, however, fluctuates signifi-

- Corresponding author. Present address: Monterey Bay Aquarium Research Institute, 7700 Sandholdt Rd., Moss Landing, California 95039, USA. E-mail: delong@mbari.org cantly both spatially and temporally (Azam et al. 1995), limiting the accuracy of global carbon cycling models. In order to understand the marine ecosystem on a large scale, there must first exist an understanding of which organisms are present, how they are distributed, and what regulates their abundance and biological activity. The oxygenic photoautotrophs are the best understood of the planktonic prokaryotes, due to their identifiable morphological traits (Waterbury et al. 1986, Olson et al. 1990, Campbell \& Vaulot 1993). Presently, generalities regarding the distribution of other prokaryote assemblages are emerging from cultivation independent 
analyses of marine bacterioplankton assemblages. DNA-DNA hybridization with total population DNA (Lee \& Fuhrman 1990, 1991), as well as rRNA or rDNA hybridization studies of specific phylogenetic groups, have indicated a high degree of population stratification in coastal and open oceans. Depth-stratified groups include a Chloroflexus-related group (Giovannoni et al. 1996), a Fibrobacter-related bacterioplankton group (SAR406; Gordon \& Giovannoni 1996), an $\propto$ proteobacteria group (SAR11; Field et al. 1997), and a $\delta$ proteobacteria group (SAR324; Wright et al. 1997). Another significant finding of cultivation independent molecular phylogenetic studies is the wide geographic distribution of many of these previously undetected bacterial groups. This suggests that there is potentially a cosmopolitan distribution of many marine prokaryotes, and that the molecular approaches are generally reliable in detecting representative groups of the bacterioplankton.

Several studies of coastal bacterioplankton abundance and activity have been conducted in the Santa Barbara Channel(SBC)-Southern California Bight region (Fuhrman \& Azam 1980, 1982, Simon \& Azam 1989, and review by Geesey 1993). Other investigations have described the significance of bacterioplankton in biogeochemical cycling in Southern California waters (Cho \& Azam 1988, 1995). Several molecularbased studies have been conducted in the same region to detect ammonia-oxidizing bacteria (Voytek \& Ward 1995), to discern the phylogenetic relationships between free-living and marine particle-associated bacteria (DeLong et al. 1993), and have also led to the discovery of the planktonic archaea (DeLong 1992, Fuhrman et al. 1992). Recent concern regarding coastal contamination, ecosystem 'health' and influences of long-term change (Hayward 1996), including changes in food web structure, underscores the relevance of understanding the ecology of coastal prokaryotic assemblages. However, little detail is known concerning the spatial and temporal variability of specific prokaryotic groups, or of the response to varying environmental conditions in SBC waters or other coastal environments.

As part of a multi-investigator effort at the University of California at Santa Barbara an interdisciplinary study was initiated to investigate inter-relationships between biological, chemical and physical variations in the center of the Santa Barbara Basin. The physical oceanographic features of the SBC are complex, as shown by recent studies of circulation (Henderschott \& Winant 1996, Harms \& Winant 1998) and water mass characteristics (Winant et al. 1996). Seasonal variations in circulation patterns have been described (Harms \& Winant 1998); phytoplankton blooms traditionally occur in spring at the time of upwelling and develop- ment of surface stratification and again in fall after dissipation of the thermocline, and bacterial biomass has been reported to be the highest in Southern California nearshore waters in August through October, when surface water temperatures are at their seasonal high (Geesey 1993). The bottom waters of the Santa Barbara Basin are seasonally anoxic (Reimers et al. 1990), and sedimentation is low due to the minimal introduction of allochthonous inorganic matter, resulting in high resolution varved sediments of biogenic and lithogenic layers suitable for fine-scale studies of the geological record (Behl \& Kennett 1996).

Planktonic archaea have recently been detected in seawater mainly by hybridization of oligonucleotide probes to rRNA or by PCR amplification and sequencing of $16 \mathrm{~S}$ rDNA genes amplified from natural planktonic biomass (DeLong 1992, Fuhrman et al. 1992, DeLong et al. 1994, Fuhrman \& Davis 1997, Massana et al. 1997,1998, McInerney et al. 1997, Murray et al. 1998, 1999). A limited number of studies has also reported on genetic or biochemical properties of these recently discovered archaea (Preston et al. 1996, Stein et al. 1996, DeLong et al. 1998, Massana et al. 1998, Preston 1998, Schleper et al. 1998a,b). A preliminary study (Massana et al. 1997) of the planktonic archaea in the SBC reported that all recoverable archaeal rDNA clones belonged to a crenarchaeal (GI) or euryarchaeal (GII) group, that the 2 groups occupied different zones of the water column, and that GI archaea constituted a significant fraction of the prokaryotic biomass. The present study was conducted with the goal of better understanding the ecological relationships between the planktonic archaea and their environment, and to determine the variability of the 2 archaeal groups over an extended time period. In combination with surveys of water column temperature, salinity, inorganic nutrients, particulate organic carbon and nitrogen, we determined prokaryote abundance, activity, chlorophyll a (chl a) concentration and relative abundance of bacterial, archaeal and eucaryal rRNA. We also monitored planktonic GI and GII archaeal groups independently (which was facilitated by use of rRNA oligonucleotide probes to each group (Massana et al. 1997) since they displayed different depth-related distributions.

\section{METHODS}

Study site and sampling. A time series study was conducted at a mooring near the center of the SBC. A mooring was deployed in spring 1994 at $34^{\circ} 17^{\prime} 32^{\prime \prime}$ N, $120^{\circ} 00^{\prime} 03^{\prime \prime}$ W (Santa Barbara Mooring Station [SBMS1]) and was then relocated in May 1995 to the

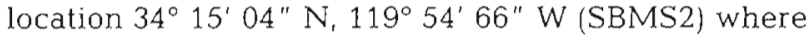
it currently resides (bottom depth $522 \mathrm{~m}$ ). This report 
covers a 32 mo period between 1 January 1995 and 20 August 1997. Seawater samples were obtained with a Niskin bottle (10 I, General Oceanics) from a boat on a bimonthly basis over the study period 164 dates sampled). A SeaBird Conductivity-Temperature-Depth system (SBE-19 CTD) was used to measure depth profiles of temperature, conductivity, and pressure. Total pigment fluorescence was measured with a Sea-Tech fluorometer fitted to the CTD system. CTD casts were conducted on all sample dates except for 9 April and 6 August 1997. Biological and chemical seawater characteristics were determined for samples collected at the surface, $10,20,30,50$, and $75 \mathrm{~m}$. Chl a concentration was measured in triplicate using standard fluorometric methods (Parsons et al. 1984). Duplicate $500 \mathrm{ml}$ samples for particulate organic carbon and particulate organic nitrogen at each depth were filtered onto Whatmann GF/F glass fiber filters and analyzed on a Control Equipment Corporation CHN Analyzer, Model 440XA, according to Sharp (1991). Seawater for nutrients was filtered through a $0.2 \mu \mathrm{m}$ pore-size syringe filter and stored frozen $\left(-30^{\circ} \mathrm{C}\right)$ until analysis by flow injection (Johnson et al. 1985). Measurements were made for ammonium ion (6 January 1995 to 8 October 1996), nitrite (6 November 1996 to 20 August 1997), combined nitrate and nitrite $\left(\mathrm{NO}_{2+3}\right)$, and phosphate (both 6 January 1995 to 20 August 1997). A subsequent report will discuss the oceanographic data in more detail. This study focuses on the relationship between environmental data and the picoplankton variables measured.

Seawater was collected at 0,20 , and $75 \mathrm{~m}$ for microbial studies. Beginning on 12 July 1995, samples were collected at additional depths of 150 and $300 \mathrm{~m}$ at monthly intervals. Four to 101 seawater samples were collected at each depth (at least $4 \mathrm{l}$ for 0,20 , and $75 \mathrm{~m}$, and $10 \mathrm{l}$ for 150 and $300 \mathrm{~m}$ samples). Seawater was stored insulated in the dark on board, and processed at the lab as soon as possible (usually within $2 \mathrm{~h}$ of collection). Subsamples were taken for picoplankton enumeration and ${ }^{3} \mathrm{H}$-leucine incorporation experiments, then the remainder of the sample was filtered for nucleic acid collection using a multichannel peristaltic pump (Millipore). Seawater was first passed through in-line polycarbonate filter holders with $1.0 \mu \mathrm{m}$ glass fiber filters (MSI), then cells were collected on $0.22 \mu \mathrm{m}$ Sterivex filters (Millipore). Though picoplankton $>1.0 \mu \mathrm{m}$ would have been excluded from our analysis, Massana et al. (1998) showed that the majority of archaeal cells reside in the $<0.8 \mu \mathrm{m}$ fraction in Antarctic waters. Lysis buffer $(1.8 \mathrm{ml}$; $40 \mathrm{mM}$ EDTA, $50 \mathrm{mM}$ Tris- $\mathrm{HCl}, 0.75 \mathrm{M}$ sucrose) was added to the Sterivex filter units after filtration and the samples were stored frozen at $-20^{\circ} \mathrm{C}$ until nucleic acid extraction.
Bacterioplankton cell abundance and leucine incorporation. Samples for bacterial abundance were preserved in glutaraldehyde ( $1 \%$ final concentration), stored at $4^{\circ} \mathrm{C}$ and enumerated, usually within 1 wk of collection. Standard methods employing DAPI staining and epifluorescence microscopy were used to enumerate the bacteria (Porter \& Feig 1980). In all cases, duplicate filters $(0.22 \mu \mathrm{m}$ black polycarbonate, Millipore) were prepared for each sample. Ten fields (averaging $>30$ cells field ${ }^{-1} ; 3 \mathrm{ml}$ for surface and $20 \mathrm{~m}$ samples, and $5 \mathrm{ml}$ for $>75 \mathrm{~m}$ samples) were counted per filter. The reported bacterial abundances were derived from the average of duplicate counts.

${ }^{3} \mathrm{H}$-leucine incorporation into protein was measured using standard methods (Kirchman et al. 1985). Seawater samples and formalin-killed controls were incubated with ${ }^{3} \mathrm{H}$-leucine $\left(180 \mathrm{Ci} \mathrm{mmol}^{-1}, 10 \mathrm{nM}\right.$ final concentration) for $120 \mathrm{~min}$ at temperatures approximating in situ conditions; averaging $15^{\circ} \mathrm{C}$ for surface, $14^{\circ} \mathrm{C}$ for $20 \mathrm{~m}$, $11^{\circ} \mathrm{C}$ for $75 \mathrm{~m}, 10^{\circ} \mathrm{C}$ for $150 \mathrm{~m}$ and $9^{\circ} \mathrm{C}$ for $300 \mathrm{~m}$ samples. After incubation, duplicated samples $(5 \mathrm{ml}$ for surface and $20 \mathrm{~m}$ samples and $10 \mathrm{ml}$ for 75,150 , and $300 \mathrm{~m}$ ) were filtered onto $0.2 \mu \mathrm{m}$ pore-size membrane filters (Millipore) in a multi-well filtration manifold (Millipore). Macromolecules were precipitated by rinsing 3 times with $3 \mathrm{ml}$ of $5 \%$ ice-cold TCA and then 2 times with $3 \mathrm{ml}$ cold $80 \%$ ethanol. The filters were dried for $1 \mathrm{~h}$, and then $0.5 \mathrm{ml}$ ethyl acetate was added to dissolve the filters. The next day, scintillation cocktail $(3.5 \mathrm{ml}$, Liquiscint, Fisher Scientific) was added to the scintillation vials, and samples were counted using a liquid scintillation counter (Beckman LS 5000 TA) with internal quench correction. Rates of leucine incorporation were determined by subtracting the DPM determined in the formalin-killed control, and then by converting DPM to picomoles of leucine incorporated per hour.

Nucleic acid extraction. Nucleic acid extraction and rRNA hybridization were as previously described (Massana et al. 1997, Murray et al. 1998). Briefly, each Sterivex filter was thawed and incubated at $37^{\circ} \mathrm{C}$ for $30 \mathrm{~min}$ in the presence of lysozyme $\left(1 \mathrm{mg} \mathrm{m}{ }^{-1}\right)$. Next, proteinase $\mathrm{K}\left(0.5 \mathrm{mg} \mathrm{m}^{-1}\right)$ and SDS ( $1 \%$ final concentration) were added, and the filter units were incubated at $55^{\circ} \mathrm{C}$ while rotating for $2 \mathrm{~h}$. Lysates were recovered from each filter unit and the filters were rinsed with $1 \mathrm{ml}$ lysis buffer for $10 \mathrm{~min}$ at $55^{\circ} \mathrm{C}$. The lysates were pooled, and then extracted with an equal volume of phenol:chloroform:isoamyl alcohol (25:24:1, $\mathrm{pH}$ 8.0), followed by extraction with an equal volume of chloroform:isoamyl alcohol $(24: 1)$. The aqueous fraction was washed 2 times with $1 \mathrm{ml} \mathrm{TE}(\mathrm{pH} \mathrm{8.0)}$ in a microconcentrator (Centricon 100, Amicon) and reduced to $100-200 \mu$ final volume. Nucleic acid concentration was determined for each extract using the Hoechst dye assay (Paul \& Myers 1982), and fluores- 
cence was determined with a fluorometer (TKO-100, Hoeffer Scientific Instruments). DNA yields varied with depth of sample collection: $1.0 \pm 0.73 \mu \mathrm{g} \mathrm{DNA} \mathrm{l}^{-1}$ seawater at $0 \mathrm{~m}(\mathrm{n}=62), 1.05 \pm 0.76 \mu \mathrm{gNA} \mathrm{l}^{-1}$ seawater at $20 \mathrm{~m}(\mathrm{n}=58), 0.70 \pm 0.41 \mu \mathrm{g} \mathrm{DNA} \mathrm{l^{-1 }}$ seawater at $75 \mathrm{~m}(\mathrm{n}=60), 0.45 \pm 0.23 \mu \mathrm{g} D \mathrm{DNA} \mathrm{l}^{-1}$ seawater at $150 \mathrm{~m}(\mathrm{n}=24)$ and $0.46 \pm 0.24 \mu \mathrm{g} \mathrm{DNA} \mathrm{l}^{-1}$ seawater at $300 \mathrm{~m}(\mathrm{n}=24)$.

rRNA hybridization analyses. rRNA oligonucleotide hybridization experiments for domain analysis of archaeal, bacterial and eukaryal rRNA in natural samples (Stahl et al. 1988, DeLong 1992, Raskin et al. 1994, Zheng et al. 1996, Massana et al. 1997, 1998, Murray et al. 1998) were the primary tool used in this study. Oligonucleotide probes specific to Eucarya (EUK 1209 GGG CAT CAC AGA CCT G, Giovannoni et al. 1988), Archaea (ARCH 915 GTG CTC CCC CGC CAA TTC CT, Amann et al. 1990b) and Bacteria (BACT 338 GCT GCC TCC CGT AGG AGT Amann et al. 1990a), and 2 different planktonic groups within the Archaea, the Crenarchaeotal Group I (GI 554 TTA GGC CCA ATA ATC MTC CT, Massana et al. 1997) and the Euryarchaeotal Group II (GII 554 TTA GGC CCA ATA AAA KCG AC, Massana et al. 1997), were used for all experiments (listed in the 5'-3' direction with Escherichia coli numbering specified for the $5^{\prime}$ base). Two universal probes (UNIV 1392 ACG GGC GGT GTG TRC, Pace et al. 1986 and UNIV1390 GAC GGG CGG TGT GTA CAA, Zheng et al. 1996) were used for normalization of the domain hybridization signals (HS). Ribosomal RNAs representing each domain were run with every set of experiments. The following $16 \mathrm{~S}$ rRNA standards were used: Eucarya: Saccharomyces cervisiae; Bacteria: Pseudomonas nautica, E. coli, or Cytophaga johnsonii; Archaea: Haloferax volcanii, Sulfolobus solfataricus or Thermoplasma acidophilum. Cenarchaeum symbiosum rRNA was included in all experiments as a control for GI rRNA. For most experiments ( $\mathrm{n}=49$ ), GI (2i) and GIl (OAR22) plasmids with rDNA inserts were used as controls. For some experiments, starting 20 November 1996 and carrying on through most of 1997 (19 total), rRNA transcripts prepared from cloned rDNA plasmids GI:SB95-57 and GII:SB95-77 (Massana et al. 1997) were used to normalize the GI and GII probe data, as described by Polz \& Cavanaugh (1997).

All nucleic extracts were applied to nylon membranes (Hybond- $N$, Amersham) using a slot blotting apparatus. Nucleic acids and control rRNAs were denatured in $0.5 \%$ glutaraldehyde $/ 50 \mathrm{mM} \mathrm{Na}_{2} \mathrm{PO}_{4}$, and the plasmid DNA was denatured by boiling for $10 \mathrm{~min}$. Each membrane had 4 samples in a 6 -fold serial dilution series (starting with $50 \mathrm{ng}$ ) and rRNA controls for each domain and archaeal group in 4 -fold dilution series. Six or 7 replicate membranes were prepared for each set of samples. After the membranes were dry, nucleic acids were UV-crosslinked to the membranes (120000 $\mu \mathrm{J} \mathrm{cm} \mathrm{cm}^{-2}$; Stratalinker, Strategene). Membranes prehybridized for $30 \mathrm{~min}$ at $45^{\circ} \mathrm{C}$ in hybridization buffer $\left(10 \mathrm{ml} ; 0.9 \mathrm{M} \mathrm{NaCl}, 50 \mathrm{mM} \mathrm{Na}_{2} \mathrm{PO}_{4}, 5 \mathrm{mM}\right.$ EDTA, 0.5\% SDS, $10 \times$ Denhardt's solution, $0.5 \mathrm{mg} \mathrm{ml}^{-1}$ polyadenosine), and then rRNA oligonucleotide probes endlabeled with ${ }^{32} \mathrm{P}$ were added. After hybridization for 8 to $16 \mathrm{~h}$, the blots were washed for $30 \mathrm{~min}$ at room temperature and then for $30 \mathrm{~min}$ at the high stringency wash temperature for each probe $\left(37^{\circ} \mathrm{C}\right.$ for UNIV 1392 and EUK $1209,45^{\circ} \mathrm{C}$ for BACT 338 and UNIV 1390 , $56^{\circ} \mathrm{C}$ for ARCH 915 , and $40^{\circ} \mathrm{C}$ for GI 554 and GII 554) in pre-warmed wash buffer $1 \mathrm{XSET} / 1 \% \mathrm{SDS}$ (1XSET: $150 \mathrm{mM} \mathrm{NaCl}, 20 \mathrm{mM}$ Tris- $\mathrm{HCl} \mathrm{pH} 7.8,2 \mathrm{mM} \mathrm{Na}_{2}$ EDTA). After drying, membrane hybridization signals were quantified with a radioanalytic gas proportional counter (Ambis, Scanalytics)

The HS of each domain was calculated as previously described by Murray et al. (1998). The amount of domain-specific probe bound per unit picoplankton IRNA was determined, and slopes were then multiplied by a probe-specific correction factor (universal probe bound per unit control rRNA $\times$ domain-specific probe bound per unit control IRNA ${ }^{-1}$ ) and divided by the amount of universal probe bound per unit picoplankton rRNA. Archaeal, bacterial and eucaryal HS were expressed as percentages of the universal probe binding. The GI and GII archaeal HS were calculated in the same manner, except that the slopes were multiplied by a group-specific probe correction factor (archaeal probe bound per unit control rRNA $x$ group-specific probe bound per unit control rRNA ${ }^{-1}$ ) and were then divided by the amount of archaeal probe bound per unit sample rRNA. The GI HS was multiplied by the percent archaea and is therefore expressed as a percent of the universal slope (designated GI HS ${ }_{1392}$ ), since native GI rRNA is available as a control (Preston et al. 1996). The GII data were normalized to a plasmid rDNA control in most cases. Once a GII rRNA transcript was available, the GII probe data were normalized to the transcript. The GII rRNA HS was always expressed as a ratio of normalized GII slope:archaeal HS and was designated GII HS archaea.

Both universal probes were used in most experiments ( $n=177$ UNIV 1390, and $n=236$ UNIV 1392) to evaluate the differences between these probes, since a report by Zheng et al. (1996) suggested a bias to archaeal rRNA with the UNIV 1392 probe, which was confirmed by other studies (Massana et al. 1998, Murray et al. 1998, 1999). The data in this report have been normalized to the UNIV 1392 probe. However, since the majority of experiments were conducted with both probes, we empirically determined that the UNIV 1392 probe overestimates the archaeal signal by a factor of 
2.09 ( $\pm 0.94 \mathrm{SD}, \mathrm{n}=177$, Murray 1998) as determined by the ratio of the archaea $\mathrm{HS}_{1392}$ to archaea $\mathrm{HS}_{1390}$. This ratio is almost identical to ratios determined for other studies investigating the Antarctic archaea (Massana et al. 1997, Murray et al. 1998, 1999).

Data analysis. Pearson correlation coefficients were calculated to determine the relationships between the measured planktonic variables and environmental variables. Nominal correlation coefficients of $r=0.3$ and significance levels of $p \leq 0.05$ were chosen, although all p-values less than 0.05 are shown in the results. Spearman rank correlations were also calculated with the same data set to determine whether outliers in the data set were skewing the Pearson correlation results. Stepwise multiple regression analyses were conducted using both forward and backward selection procedures to help identify the physical, chemical, and biological (independent) variables that were most useful in explaining or predicting the archaeal HS, bacterial abundance, and the leucine incorporation rate (dependent variables). Forward models add independent variables in the order of their ability to predict the dependent variable, and backward models start with all variables in the model, and remove the ones that are least useful in predicting the dependent variable. Default settings employing the partial F-ratio as criteria for adding or deleting variables were used. Statistical analysis was performed with StatView ver. 5.0 (SAS).

\section{RESULTS}

\section{Oceanographic conditions in the SBC, January 1995 to August 1997}

Contour plots displaying annual variation through the upper $75 \mathrm{~m}$ of temperature, chl $a_{1}$ and $\mathrm{NO}_{2+3}{ }^{-}$concentrations are shown in Fig. 1. There was a high degree of interannual variation in chl a concentration, which coincided with interannual variations in temperature and inorganic nutrient concentration. The data collected in 1995 showed intense phytoplankton blooms (indicated by chl a concentrations exceeding $39 \mu \mathrm{g} \mathrm{l}^{-1}$ at the surface), coincident with low temperatures, and higher salinity and density. The data collected in 1996 showed less variability than that observed in 1995, though spring phytoplankton blooms were detected (chl a concentrations approached $10 \mathrm{\mu g}^{-1}$ on 2 occasions in surface waters). In
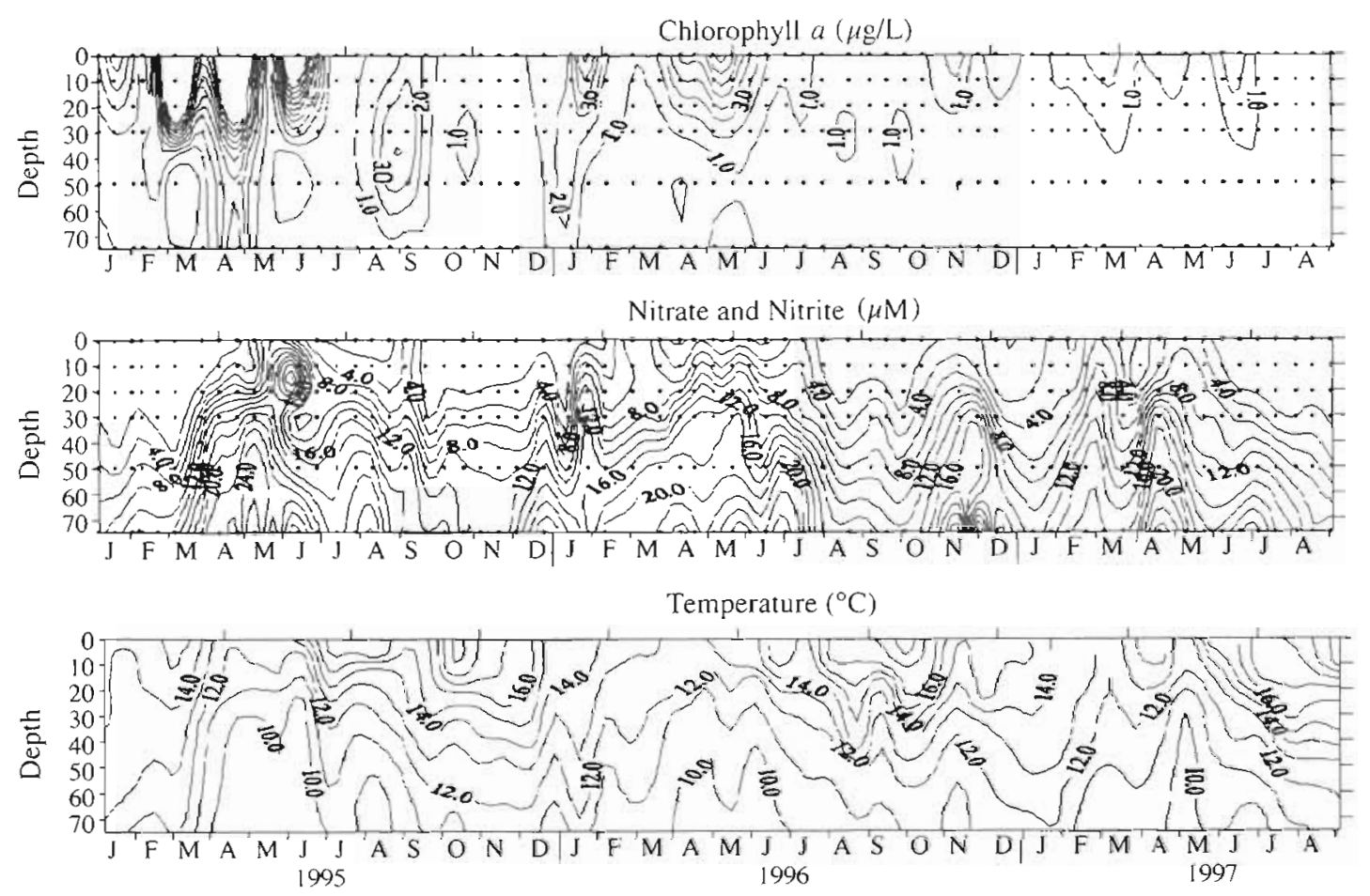

Fig. 1. Contour plots of chl a concentration $\left(\mu g \mathrm{l}^{-1}\right), \mathrm{NO}_{2+3}(\mu \mathrm{M})$ and temperature $\left({ }^{\circ} \mathrm{C}\right)$ at Santa Barbara Mooring Stns 1 and 2 (SBMS1 and SBMS2) throughout the time series. Contours for chlorophyll are $1 \mu \mathrm{g} \mathrm{l}^{-1}$, although the scale was not appropriate for spring 1995, where concentrations were as high as $39 \mu \mathrm{gl}^{-1}$. Contours are $2 \mu \mathrm{m}$ for $\mathrm{NO}_{2+3}$ and are $1^{\circ} \mathrm{C}$ for temperature. Sample collection depths are shown with dots for chlorophyll and $\mathrm{NO}_{2+3}$. Temperature data were measured with a CTD, and averaged into $1 \mathrm{~m}$ bins 
1997 the SBC experienced conditions brought on by El Niño, including low winds, early surface stratification and low nutrients. These conditions likely influenced the lack of chl a accumulation in surface waters in spring 1997 (chl a concentrations peaked at $5.5 \mu \mathrm{g} \mathrm{l}^{-1}$ 11 June, Fig. 1). Overall temperatures (for the $32 \mathrm{mo}$ time course) were more stable at depth $\left(10,5^{\circ} \mathrm{C}, \mathrm{CV}=\right.$ 0.07 at $75 \mathrm{~m}$ as compared to $15.6^{\circ} \mathrm{C}, \mathrm{CV}=0.14$ at the surface).

Several water masses and mixtures thereof are found in the SBC. Based on recent work by Winant et al. (1996), the water most commonly sampled at SBMS2 in our 32 mo study had the temperature/salinity characteristics of SBC and Upwelling water masses. Temporal variability in water mass was high particularly in spring-early summor 1995 when different water masses were sampled on almost every sampling date. During spring 1996, upwelling water was sampled on every occasion, in contrast to spring 1997 when samples from only 3 dates indicated upwelled water, likely a result of El Niño conditions in the channel. The salinities in all samples from mid-July to December generally indicated SBC water. The depth of the mixed layer (MLD) was defined by the depth at which the change in temperature was $0.5^{\circ} \mathrm{C}$ lower than the temperature at $2 \mathrm{~m}$ (data was binned at $1 \mathrm{~m}$ depth intervals, and also checked at changes in temperature of 0.1 and $0.2^{\circ} \mathrm{C}$ ).

\section{Methodological considerations}

In this study we used small subunit IRNA oligonucleotide probes to estimate the relative contributions of bacteria, eukaryotes and archaea, and 2 archaeal subgroups (GI and GII) to estimate the $<1.0 \mu \mathrm{m}$ picoplankton fraction in the SBC at 5 different depths over a 32 mo period. Attempts were made throughout this study to use consistent sample processing and extraction procedures. The amount of nucleic acid required for sample analysis (and total numbers of samples analyzed) precluded analysis of replicate samples on a regular basis. However, to provide an approximation of the experimental precision of the $\mathrm{HS}$ determinations, experiments were conducted to assess the variability within individual hybridization experiments using the domain- and group-specific probes. Standard deviations averaged $23.8,9.7,3.9,24.7$ and $12.9 \%$ (over 3 depths) of the total HS calculated for EUK 1209, BACT 338, ARCH 915, GI 554, and GII 554 probes respectively.

Identical rRNA controls were used in nearly all hybridization experiments. Evaluation of experimental correction factors (cf. universal probe bound (groupspecific $\mathrm{HS}^{-1}$ ) determined for each probe also indicated minimal variation. The cf for the probes normalized to the UNIV 1392 probe ranged as follows for a total of 68 experiments: $1.05 \pm 0.35$ for EUK 1209, $0.36 \pm 0.19$ for BACT 338, $0.43 \pm 0.16$ for ARCH 915, $1.50 \pm 0.54$ for GI 554 normalized to Cenarchaeum symbiosum rRNA, $1.48 \pm 0.54$ for the GI 554 normalized to the GI plasmid DNA, and $1.33 \pm 0.72$ wher nor.

Table 1. Summary of hybridization, prokaryote abundance, and leucine incorporation data collected at Santa Barbara Mooring Station (SMBS2) from 23 May 1995 to 20 August 1997. The hybridization signal (HS) values are expressed as percentages of UNIV 1392 or archaeal probe binding, as indicated by subscripts (see 'Methods')

\begin{tabular}{|c|c|c|c|c|c|c|c|}
\hline Variable & Depth (m) & Mean & $\mathrm{SD}$ & Min. & Max. & CV & $\mathrm{n}$ \\
\hline \multirow[t]{5}{*}{ Arch $\mathrm{HS}_{1392}$} & 0 & 8.01 & 8.20 & 0.70 & 49.00 & 1.02 & 53 \\
\hline & 20 & 11.47 & 1.0 .50 & 1.70 & 53.30 & 0.92 & 52 \\
\hline & 75 & 31.02 & 13.80 & 6.37 & 61.60 & 0.45 & 53 \\
\hline & 150 & 34.20 & 17.86 & 4.63 & 67.90 & 0.52 & 25 \\
\hline & 300 & 39.17 & 13.44 & 4.68 & 39.00 & 0.34 & 24 \\
\hline \multirow[t]{5}{*}{ GI $\mathrm{HS}_{1392}$} & 0 & 0.63 & 0.83 & 0.00 & 3.59 & 0.68 & 52 \\
\hline & 20 & 1.95 & 2.48 & 0.00 & 11.11 & 1.27 & 52 \\
\hline & 75 & 22.27 & 11.07 & 5.84 & 51.60 & 0.50 & 52 \\
\hline & 150 & 23.59 & 8.99 & 5.56 & 41.45 & 0.38 & 22 \\
\hline & 300 & 30.49 & 9.52 & 10.54 & 46.13 & 0.31 & 21 \\
\hline \multirow[t]{5}{*}{ GII HSarchaea } & 0 & 0.49 & 0.41 & 0.00 & 1.39 & 0.83 & 52 \\
\hline & 20 & 0.48 & 0.43 & 0.03 & 1.44 & 0.90 & 52 \\
\hline & 75 & 0.12 & 0.12 & 0.00 & 0.54 & 1.02 & 52 \\
\hline & 150 & 0.08 & 0.10 & 0.00 & 0.39 & 1.33 & 25 \\
\hline & 300 & 0.08 & 0.10 & 0.00 & 0.34 & 1.24 & 23 \\
\hline \multirow[t]{5}{*}{ EUK $\mathrm{HS}_{1392}$} & 0 & 24.35 & 12.55 & 10.20 & 64.30 & 0.52 & 48 \\
\hline & 20 & 23.01 & 12.17 & 3.10 & 57.10 & 0.51 & 48 \\
\hline & 75 & 9.28 & 5.59 & 0.00 & 25.50 & 0.60 & 47 \\
\hline & 150 & 5.82 & 5.34 & 0.00 & 21.60 & 0.92 & 22 \\
\hline & 300 & 6.51 & 5.45 & 0.00 & 21.70 & 0.84 & 23 \\
\hline \multirow[t]{5}{*}{ BACT $\mathrm{HS}_{1392}$} & 0 & 77.13 & 18.28 & 38.20 & 132.00 & 0.24 & 48 \\
\hline & 20 & 73.88 & 24.21 & 31.80 & 139.70 & 0.33 & 48 \\
\hline & 75 & 50.31 & 17.04 & 15.30 & 96.10 & 0.34 & 47 \\
\hline & 150 & 41.14 & 9.38 & 26.20 & 56.80 & 0.23 & 22 \\
\hline & 300 & 44.53 & 12.45 & 23.00 & 69.80 & 0.28 & 23 \\
\hline \multirow{5}{*}{$\begin{array}{l}\text { Prokaryote abun- } \\
\text { dance }\left(10^{8} \text { cells } 1^{-1}\right)\end{array}$} & 0 & 10.57 & 3.62 & 4.56 & 27.90 & 0.34 & 54 \\
\hline & 20 & 9.60 & 3.99 & 4.26 & 26.90 & 0.42 & 54 \\
\hline & 75 & 4.69 & 1.36 & 1.54 & 7.60 & 0.29 & 54 \\
\hline & 1.50 & 4.14 & 1.59 & 1.96 & 8.78 & 0.39 & 25 \\
\hline & 300 & 3.94 & 1.30 & 1.63 & 6.81 & 0.33 & 24 \\
\hline \multirow{5}{*}{$\begin{array}{l}\text { Leucine incorpor- } \\
\text { ation }\left(\mathrm{pM} \mathrm{h}^{-1}\right)\end{array}$} & 0 & 580.28 & 524.44 & 54.50 & 2840.00 & 0.90 & 30 \\
\hline & 20 & 349.55 & 269.87 & 24.30 & 950.90 & 0.77 & 30 \\
\hline & 75 & 32.00 & 28.41 & 1.20 & 116.60 & 0.89 & 30 \\
\hline & 150 & 22.05 & 17.23 & 3.14 & 64.39 & 0.78 & 16 \\
\hline & 300 & 10.11 & 12.65 & 0.00 & 45.40 & 1.25 & 15 \\
\hline
\end{tabular}


malized to the GI rRNA transcript. The of for the GII 554 probe was $1.21 \pm 0.72$ when normalized to GII plasmid rDNA and $4.00 \pm 2.02$ when normalized with the GII 57-95 rRNA transcript. Due to the differences in the binding efficiencies of the probe to the plasmid rDNA and the rRNA transcript, the GII signals reported in the majority of the experiments estimated by correction with the plasmid DNA may be underestimated by a factor of 4 . The GII rRNA transcript was likely more representative of native $\mathrm{RNA}$, since slopes normalized with the correction factors derived using the transcript data averaged $0.57 \pm 0.45$ of the archaeal signal, in contrast to $0.15 \pm 0.19 \%$ when the GII plasmid DNA was used as a control.

\section{Picoplankton composition in the SBC}

The results of the hybridization experiments are summarized in Table 1 . The archaeal HS in surface waters averaged approximately $10 \%$ of the bacterial signal ( $8 \%$ of the UNIV $\left.\mathrm{HS}_{1392}\right)$, and $33 \%$ of the eucaryal signal in the cellular fraction passing the $1.0 \mu \mathrm{m} \mathrm{GF/F}$ filter. Deeper in the water column, the relative contribution of the archaeal HS was higher, approached that of the bacterial HS (average 39.2 compared to $44.5 \% \mathrm{HS}$ at $300 \mathrm{~m}$ ), and greatly exceeded the eucaryal HS by a factor of 6 (Table 1). Variability in the archaeal signal indicated by the coefficient of variation (CV) showed that the archaeal HS was much more variable in surface waters (1.02) compared to depth $(0.34$ at $300 \mathrm{~m})$. The eucaryal $\mathrm{HS}_{1392}$ was consistently low since only the less than $1.0 \mu \mathrm{m}$ cellular fraction was collected, and decreased from $24.4 \%$ at the surface to $6.5 \%$ at $300 \mathrm{~m}$. The variability of the eucaryal signal increased with depth (CV 0.52 in surface waters compared to 0.92 at $150 \mathrm{~m}$ ) while the bacterial HS dominated the rRNA at all depths $\left(61.4 \pm 23.3 \% \mathrm{HS}_{1392}\right.$ over all depths) and was more stable, with CVs ranging between 0.23 and 0.42 for all depths investigated.

The crenarchaeotal (GI) and euryarchaeotal (GII) planktonic archaea were found to consistently inhabit distinct depth strata in the water column. The archaeal and GI hybridization data for discrete samples at 5 depths sampled throughout the 32 mo time series are shown in Fig. 2. The surface archaeal signal was substantially lower than the samples from $75 \mathrm{~m}$ and deeper (see averages in Table 1). The lack of agreement between the GI and archaeal $\mathrm{HS}_{1392}$ in the upper $20 \mathrm{~m}$ suggested that GII was responsible for the majority of the archaeal signal in surface waters. Detectable rRNA HS from GII archaea was almost exclusively limited to the upper water column $(20 \mathrm{~m}$ and above, Fig. 3). Temporally, the GII archaeal signal was quite variable, as indicated by the reported SDs and CVs (Table 1). Intermittent surface 'blooms' in archaeal $\mathrm{HS}_{1392}$ were associated with peaks in the GII HS archaea. The GI HS archaea never exceeded $11.4 \%$ in surface waters or $20.8 \%$ in $20 \mathrm{~m}$ waters throughout the study.

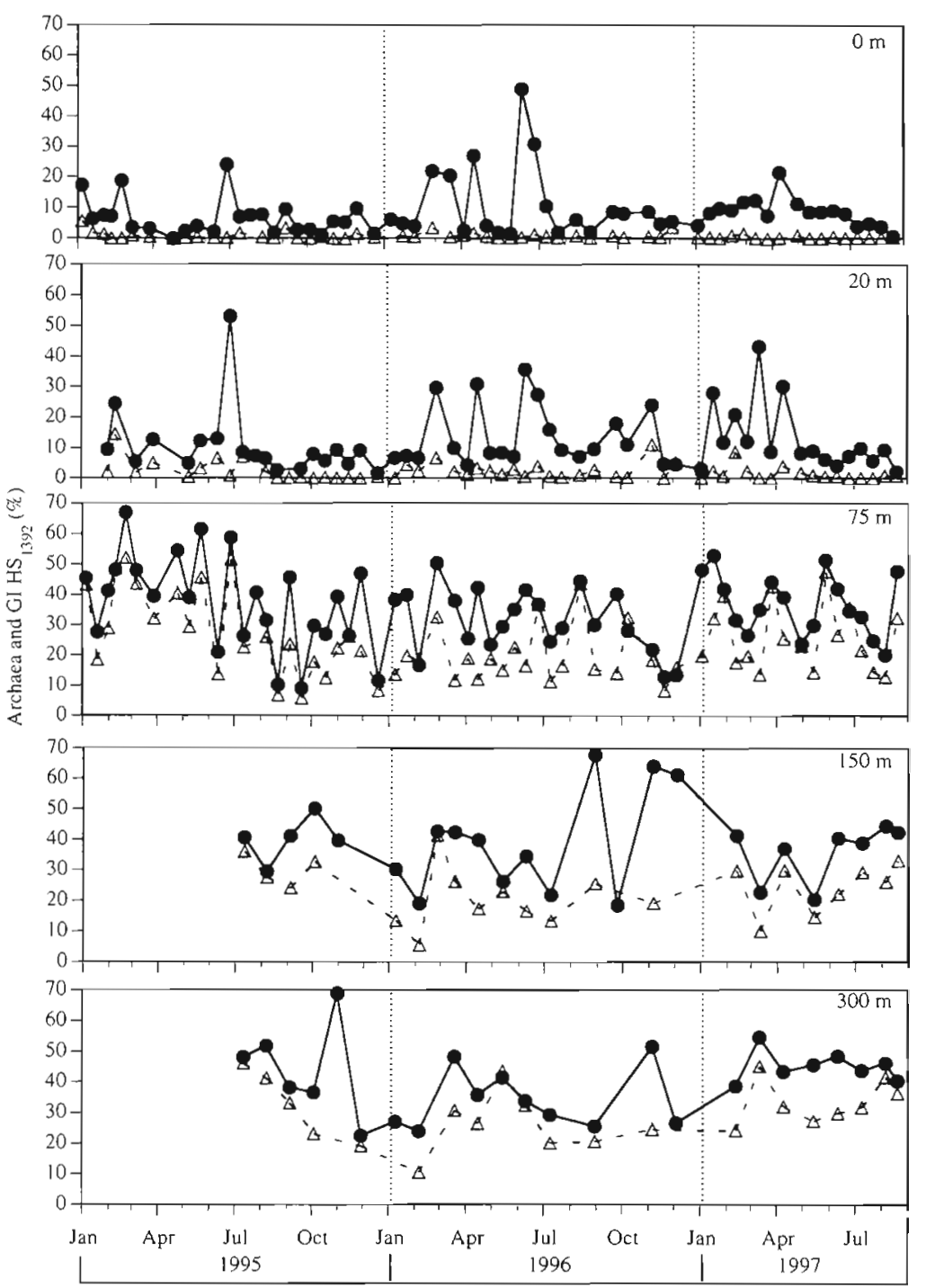

Fig. 2. Temporal variability in the hybridization signal (HS) at SBMS1 and SBMS2 between 1 January 1995 and 20 August 1997. Archaeal ( and and GI ( $\triangle$ and - . - ) HS $_{1392}$ represented as percents of the universal HS were plotted for each depth from which samples were collected. (The archaeal $\mathrm{HS}_{1392}$ overestimates the archaeal $\mathrm{HS}_{1390}$ by a factor of 2 ) 

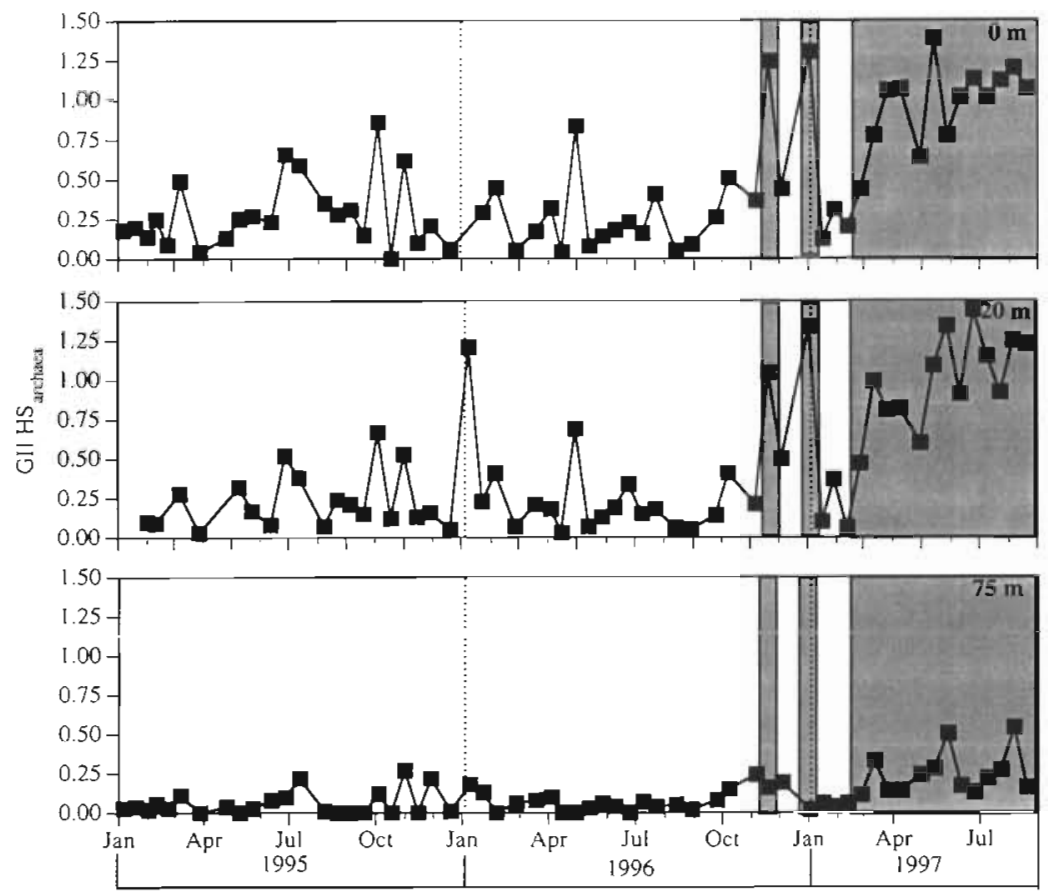

Fig. 3. Variation in the GII $\mathrm{HS}_{\text {archaed }}$ (corrected slope for the GII $\times$ archaeal slope $^{-1}$ ) at SBMS1 and SBMS2 between 1 January 1995 and 20 August 1997 for samples collected at the surface, 20 and $75 \mathrm{~m}$. The GII HS archaed 150 and 300 $\mathrm{m}$ was not shown since levels were consistently low, averaging $0.08 \pm 0.10 \mathrm{SD}$ at both depths and never exceeding 0.39 and 0.34 at 150 and $300 \mathrm{~m}$ respectively. Shaded portions represent HS data that were normalized to the rRNA transcript (which had a correction factor 4 -fold higher than for the same probe binding the GII plasmid encoded DNA)

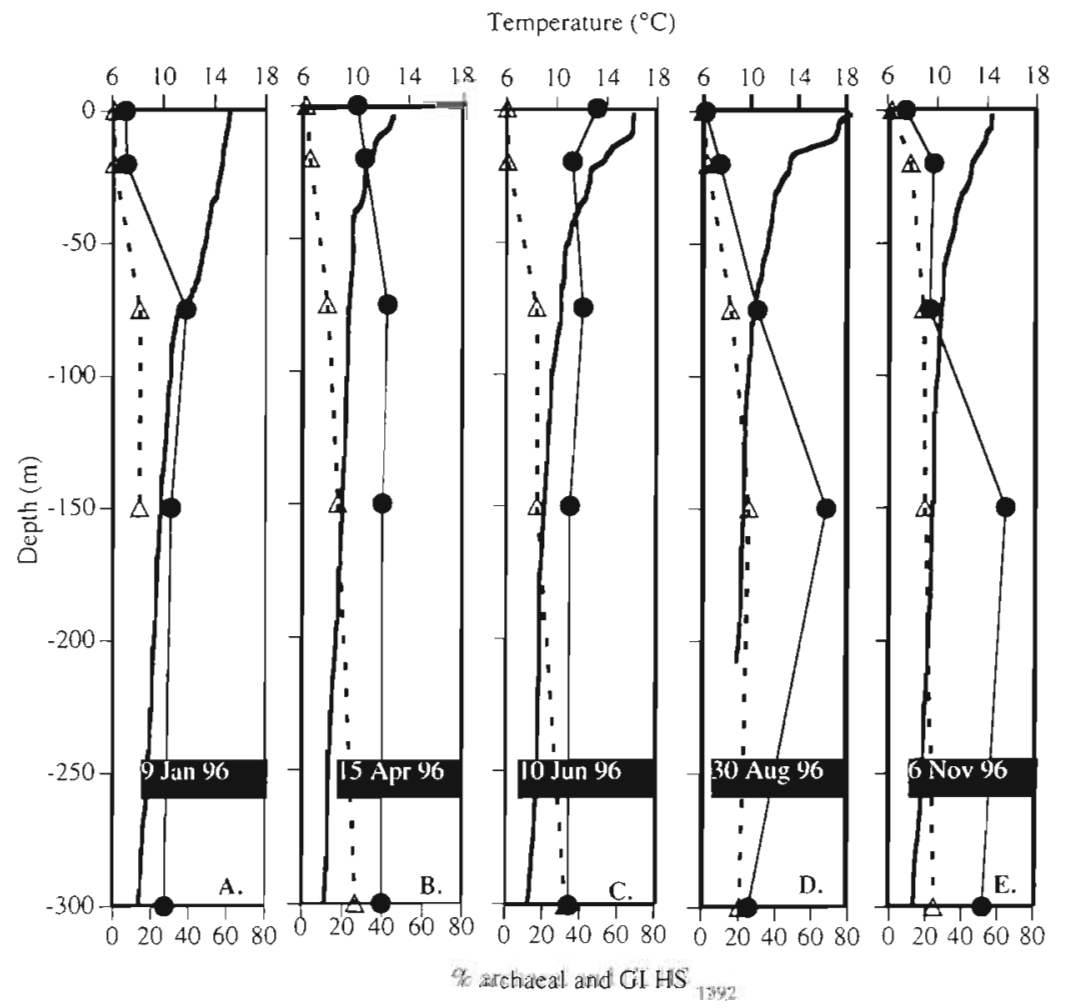

The GI HS was substantially higher at depths $\geq 75 \mathrm{~m}$ (accounting for $70.1 \%$ of the archaeal signal and 22.2 to $30.5 \%$ of the universal $\mathrm{HS}_{1392}$ ).

Selected vertical profiles of archaeal rRNA from 5 dates in 1996 (Fig. 4) demonstrate the dynamic nature of planktonic archaeal distribution in the water column. Occasional increases of archaeal rRNA in surface waters were not explained by the GIHS. In late summer and fall 1996 there was a peak at $150 \mathrm{~m}$ of both archaeal and GI rRNA. At depth, the GI HS dominated the planktonic archaeal signal. In total, profiles collected from 22 hydrocasts to $300 \mathrm{~m}$ (with data collected from all 5 depths) indicated peaks in the archaeal signal at $75 \mathrm{~m}$ for $23 \%$ of the casts, and at $150 \mathrm{~m}$ for $18 \%$ of the casts. The remaining majority of hydrocasts (59\%) indicated the highest relative archaeal rRNA abundance at $300 \mathrm{~m}$.

Correlations between the archaeal HS and water column physical conditions were investigated, but did not indicate any significant trends. Distinct changes in \% archaeal HS were detected within the same water mass (at least on the resolution of the time series), as well as in different water masses (Murray 1998). Detailed examination of variability in temperature measured at high frequency (every $1.5 \mathrm{~h}$ ) using temperature data loggers (Hobo Temp) in 1996 and 1997 did not show a correlation between temperature and archaeal HS at the surface or $75 \mathrm{~m}$ (data not shown). Linear regression of the archaeal, GI and GII hybridization data with the MLD did not indicate a significant relationship between archaeal distribution and the depth of the upper mixed layer (Murray 1998). Collection of

Fig. 4. Vertical profiles of archaeal and GI $\mathrm{HS}_{1392}$ during different seasons throughout 1996. In all cases: and - $\longrightarrow$ archaeal $\mathrm{HS}_{1392}$ and $(\Delta$ and - - - ) GI HS 1392 . Temperature is shown with the thicker solid line, data collected with a SBE19 CTD. Water column conditions were: (A) Vertically mixed water column, deep thermocline $(75 \mathrm{~m})$; (B) typical spring upwelling conditions, weak thermocline at $45 \mathrm{~m}$; (C) development of stratification, shallow surface mixed layer (upper $10 \mathrm{~m}$ ); (D) stratified upper water column with intense thermocline; and $(E)$ breakdown of the thermocline 

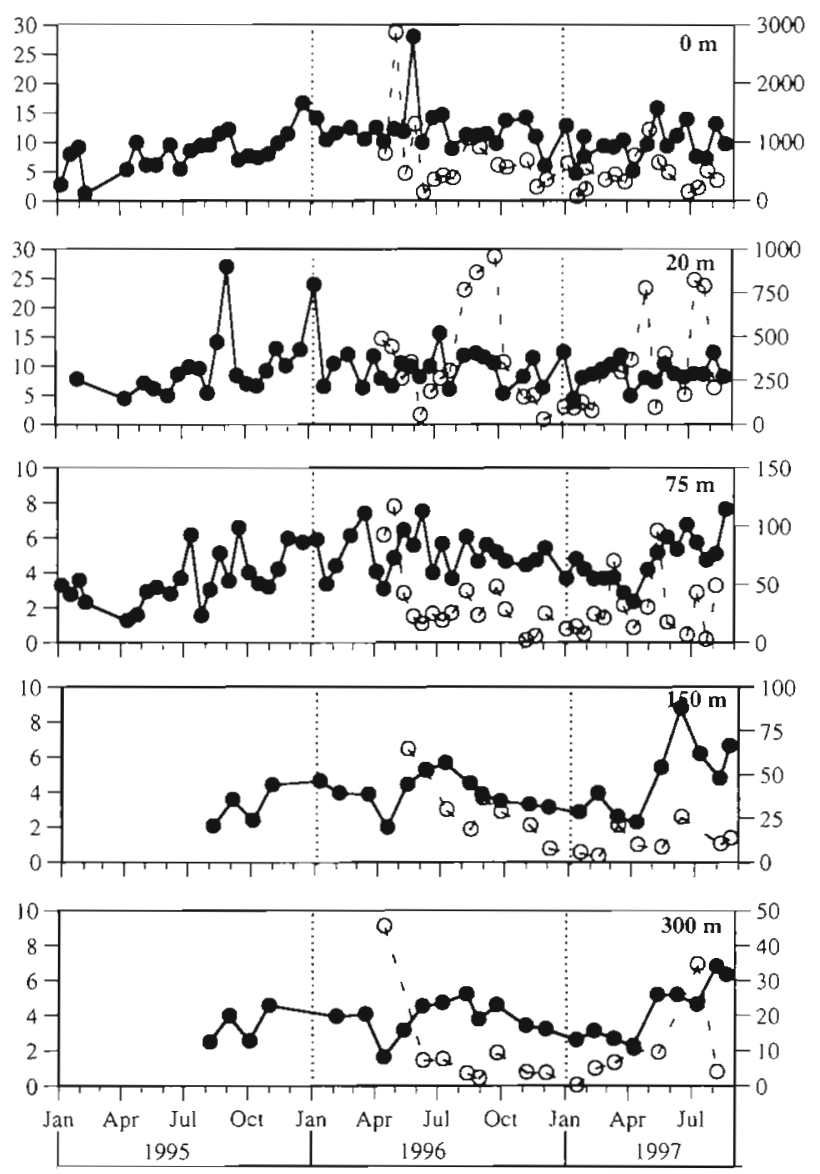

Fig. 5. Temporal variation in prokaryote abundance (DA.PIstained cells $\times 10^{8} \mathrm{cells}^{-1}$ ) ( and - $\longrightarrow$ ) and leucine incorporation rate $\left(\mathrm{pM} \mathrm{h}^{-1}\right)(\triangle$ and - - - ) at SBMS 1 and SBMS2 at all depths sampled. Different scales were used to account for changes in abundance and activity with depth

samples at only 5 depths might not have provided sufficient resolution to reveal the actual in situ vertical distributions.

Prokaryote abundance and leucine incorporation data for the 32 mo study are shown in Fig. 5 and summarized in Table 1. Cell concentrations in surface and $20 \mathrm{~m}$ waters were consistently 2 -fold higher than counts at 75,150 , or $300 \mathrm{~m}$. Prokaryote abundance determined by counting DAPI-stained cells showed little variation at all depths, with the $\mathrm{CV}$ ranging between 0.29 and 0.42. Cellular abundance did not show a significant seasonal signal, though one dramatic increase at the surface (approaching $3 \times 10^{9} \mathrm{cells}^{-1}$ on 28 May 1996) coincided with a phytoplankton bloom and POC accumulation. Two bacterioplankton blooms at $20 \mathrm{~m}$ (approaching $3 \times 10^{9}$ cells $\mathrm{l}^{-1}$ ) coincided with an increase in temperature (September 1995), after a midwinter phytoplankton bloom (when chl a concentrations were $4.27 \mu \mathrm{g} \mathrm{I}^{-1}$ on 20 December 1995, and $3.16 \mathrm{\mu g}^{-1}$ on 9 January 1996), and accumulated POC in the upper water column (338 $\mu \mathrm{g} \mathrm{l}^{-1}$ on 20 December 1995 and $181 \mathrm{\mu g} \mathrm{l}^{-1}$ on 9 January 1996). Leucine incorporation rates were much more variable than the prokaryote counts at the same depths, showing only significant activity in the surface and $20 \mathrm{~m}$ samples. The average at $75 \mathrm{~m}$ was more than a factor of 10 -fold lower than the activity at $20 \mathrm{~m}$. Peaks in bacterial activity (inferred from leucine incorporation), particularly for the $20 \mathrm{~m}$ samples, were observed in spring and summer of 1996 and 1997

\section{Statistical analyses}

Significant differences were found between the oceanographic parameters recorded at the 2 buoy locations (SBMS1 and SMBS2). When the 2 data sets (SBMS1 and 2, and SBMS2 only) were compared by $t$-test, temperature, chl a, C:N ratio, eucaryal and bacterial $\mathrm{HS}_{1392}$, were all significantly ( $\mathrm{p} \leq 0.05$ ) higher in the SBMS1 and 2 data set. Sigma-t and the GI HS H.392 $_{2}$ were significantly higher in the SBMS2 data set. Together these findings implied that the 2 sites were substantially different and the data sets should be considered separately. The SBMS2 data set was evaluated by correlation and stepwise regression analysis, since a more complete data set $(22 \mathrm{mo})$ was available for that location.

A large number of pairwise correlations were conducted in this study (378). With such high numbers of experiments, the chance of getting 1 or more significant results can be much higher than the chance for any individual test, so that the tests should not be taken as decisive. We have presented p-values ( $p<$ 0.05 , Fisher's Z-test) for fair consideration of the significance of these data.

Multiple pairwise correlation results are summarized for the archaeal, GI and GII HS data (Table 2A) in which the correlation coefficients were determined for the archaeal HS data compared to environmental parameters. In most cases significant $(p \leq 0.05)$ Pearson correlations were also significant $(p \leq 0.05)$ with the Spearman rank correlation. In the surface waters total archaeal $\mathrm{HS}_{1392}$ correlated positively with $\mathrm{NO}_{2}^{-}$, and the GII signal was correlated with stratified conditions (negative correlations with sigma-t, $\mathrm{NO}_{2}{ }^{-}$and eucaryal rRNA). The small GI signal in surface waters was correlated with conditions indicative of upwelled water (negative correlation with temperature, positive correlation with sigma-t, $\mathrm{NO}_{2+3}{ }^{-}, \mathrm{PO}_{4}{ }^{2-}$ and $\mathrm{SiO}_{4}$ ). Note that nitrite was determined between 6 November 1996 and 20 August 1997, whereas the combined nitrate and nitrite concentrations were determined throughout the entire study. At $20 \mathrm{~m}$ similar results were found. The archaeal signal was correlated positively with $\mathrm{NO}_{2}^{-}$ 


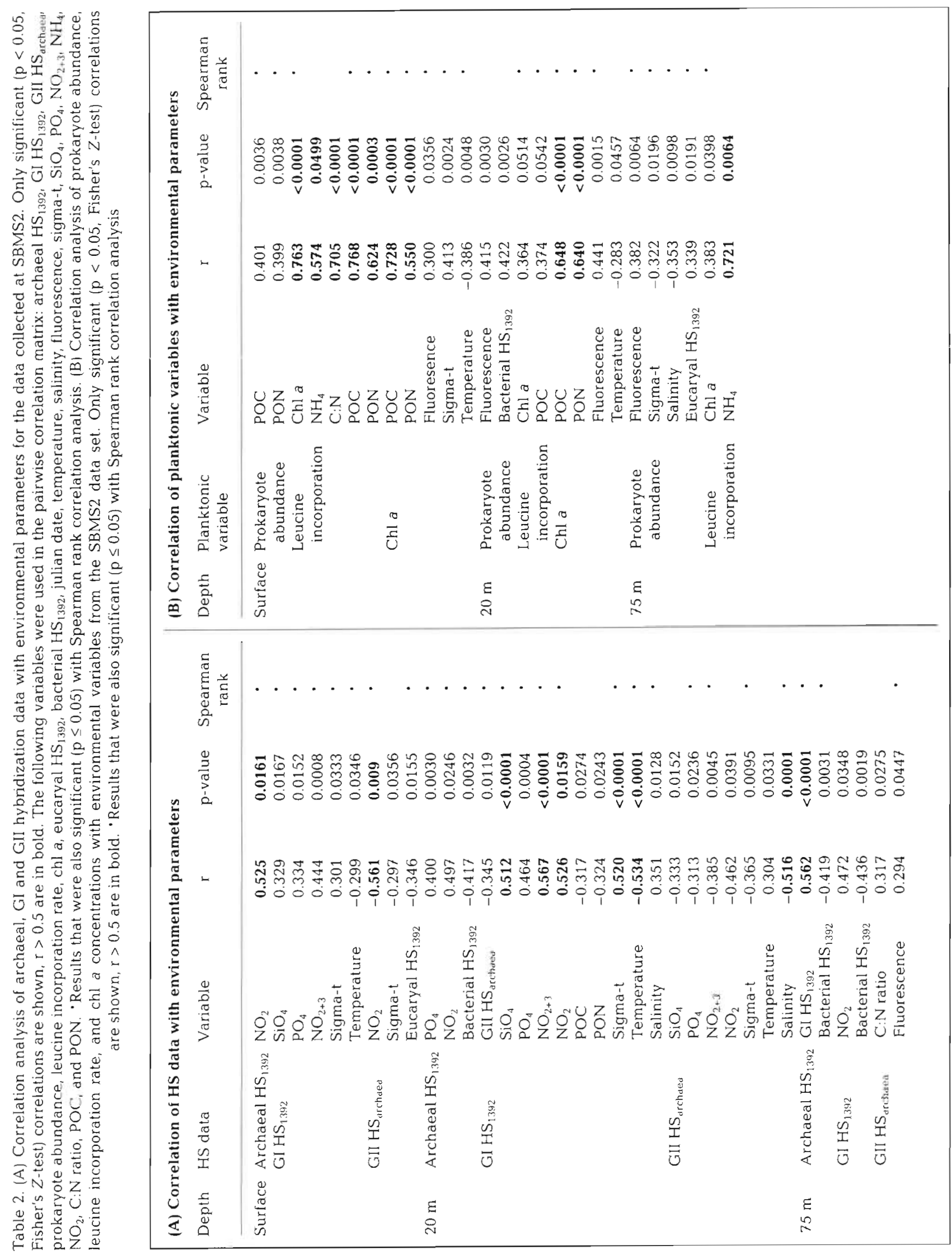


and $\mathrm{PO}_{4}{ }^{2-}$, and negatively with bacterial rRNA HS. GI levels correlated with characteristics of upwelled water. Negative correlations were also significant between the GI HS and POC, PON, and GII rRNA, which is consistent with speculations that the GI and GII inhabit distinct water column strata, and that the GI planktonic archaeal rRNA is not found in conditions of high biomass (Murray et al. 1998, 1999). The GI signal also showed a positive relationship with $\mathrm{NO}_{2}^{-}$. The positive correlations with $\mathrm{NO}_{2}^{-}$are suggestive of a relationship, but are not as strong as for the other variables measured due to the low number of samples in which nitrite was measured $(n=20)$.

Correlations between environmental variables prokaryote abundance, leucine incorporation, and chl a concentrations are summarized in Table 2B. Conditions in the surface waters showed a significant positive correlation between prokaryote abundance and leucine incorporation with POC. Leucine incorporation was also positively correlated with chl a. Chl a levels correlated significantly with upwelling conditions (low temperature and higher sigma-t), fluorescence and POC. At $20 \mathrm{~m}$ similar findings suggested the occur- rence of higher prokaryotic abundance with fluorescence, chl $a$, and bacterial rRNA. Leucine incorporation also covaried with chl a and POC, though the correlation coefficients were not as high as those determined for the surface samples. Prokaryote abundance at $75 \mathrm{~m}$ correlated negatively with salinity and positively with fluorescence and eucaryal rRNA (suggesting intermittent mixing conditions), Leucine incorporation at $75 \mathrm{~m}$ was positively correlated again with chl a as was seen in the surface waters. Linear regressions of prokaryote abundance or leucine incorporation and temperature at each depth sampled indicated that there was no significant correlation between these variables in the SBC.

Stepwise regression analyses conducted on the GI and GII $\mathrm{HS}_{1392}$ data (Table 3) supported the results of the correlation analysis, and indicated variables potentially significant in influencing the archaeal group HSs determined. In the surface waters, the variables used in the analysis did not account for the variability in either archaeal subgroup. At $20 \mathrm{~m}, \mathrm{POC}$ and $\mathrm{NO}_{2+3}^{-}$contributed to $41 \%$ of the variability in the GI archaeal signal. The variance in the GII HS was not due to the vari-

Table 3. Summary of stepwise regression results for the SBMS2 data set. All independent variables listed were included in the analysis, only significant variables left in the model are reported. All variables except GII HS, temperature and salinity were log transformed due to non-normal distributions. Colinear variables with correlation coefficients $\geq 0.8$ were not analyzed. Both forward $(F)$ and backward (B) stepwise regressions (Reg.) were performed. The GII data normalized with the rRNA transcript were not included in the analyses. Probability values $\leq 0.05$ are indicated in bold

\begin{tabular}{|c|c|c|c|c|c|c|c|c|c|c|c|c|c|}
\hline \multirow{2}{*}{$\begin{array}{l}\text { Dependent } \\
\text { variable }\end{array}$} & \multirow{2}{*}{$\begin{array}{l}\text { Depth } \\
\text { (m) }\end{array}$} & \multirow[b]{2}{*}{$\begin{array}{l}\text { Temp. } \\
\left({ }^{\circ} \mathrm{C}\right)\end{array}$} & \multirow[b]{2}{*}{$\begin{array}{l}\text { Salinity } \\
\left(\% \%_{0}\right)\end{array}$} & \multicolumn{4}{|c|}{ - Independent variables } & \multirow{2}{*}{\multicolumn{2}{|c|}{$\begin{array}{c}\log \quad \log \\
\text { prokaryote leucine }\end{array}$}} & \multirow[t]{2}{*}{$\mathrm{R}^{2}$} & \multirow{2}{*}{$\mathrm{p}$-value } & \multirow{2}{*}{ Reg. } & \multirow{2}{*}{$\mathrm{n}$} \\
\hline & & & & $\begin{array}{l}\log \\
\operatorname{chl} a\end{array}$ & $\begin{array}{l}\text { Log } \\
\text { POC }\end{array}$ & $\begin{array}{l}\text { Log } \\
\text { C:N }\end{array}$ & $\begin{array}{c}\mathrm{Log} \\
\mathrm{NO}_{2+3}\end{array}$ & & & & & & \\
\hline Log GI $\mathrm{HS}_{1392}$ & 0 & & & & & & 0.365 & & - & 0.088 & 0.0627 & $\mathrm{~B}$ & 40 \\
\hline GII HS $\mathrm{H}_{\text {archeea }}$ & 0 & 0.020 & & & & & & -0.314 & - & 0.085 & 0.2654 & $\mathrm{~B}$ & 33 \\
\hline Log prokaryote & 0 & & & & & & & - & 0.198 & 0.184 & 0.0365 & $F+B$ & 24 \\
\hline Log leucine & 0 & 0.053 & -1.215 & & 1.365 & & & & - & 0.604 & 0.0003 & $\mathrm{~F}+\mathrm{B}$ & 24 \\
\hline Log GI HS 1392 & 20 & & & & -0.847 & & 0.627 & & - & 0.413 & $<0.0001$ & $\mathrm{~F}+\mathrm{B}$ & 38 \\
\hline GII $\mathrm{HS}_{\text {archaea }}$ & 20 & & -0.385 & & & 0.580 & & & - & 0.040 & 0.5194 & $\mathrm{~B}$ & 35 \\
\hline Log prokaryote & 20 & & & & & & & - & -0.083 & 0.068 & 0.2279 & $\mathrm{~B}$ & 23 \\
\hline Log leucine & 20 & & & 1.004 & -0.359 & 2.489 & & & - & 0.711 & $<0.0001$ & B & 23 \\
\hline Log GI HS 1392 & 75 & & & -0.115 & -0.121 & & 0.238 & -0.390 & - & 0.242 & 0.0206 & $\mathrm{~B}$ & 46 \\
\hline GII HS archaea & 75 & 0.037 & & & & & & & - & 0.132 & 0.0294 & $\mathrm{~F}+\mathrm{B}$ & 36 \\
\hline Log prokaryote & 75 & 0.091 & 0.356 & & 0.386 & & & - & & 0.355 & 0.0362 & $\mathrm{~B}$ & 23 \\
\hline Log leucine & 75 & -0.191 & & 0.242 & 0.652 & & & & - & 0.338 & 0.0451 & $\mathrm{~B}$ & 23 \\
\hline $\log$ GI HS 1392 & 150 & 0.104 & & - & - & - & - & & - & 0.057 & 0.3570 & B & 17 \\
\hline GII $\mathrm{HS}_{\text {archaea }}$ & 150 & & & - & - & - & - & 0.094 & - & 0.085 & 0.3345 & B & 13 \\
\hline Log prokaryote & 150 & 0.184 & & - & - & - & - & - & & 0.232 & 0.1129 & B & 12 \\
\hline Log leucine & 150 & & 2.341 & - & - & - & - & & - & 0.270 & 0.0833 & B & 12 \\
\hline Log GI HS 1392 & 300 & 0.135 & & - & - & - & - & & - & 0.124 & 0.1803 & B & 16 \\
\hline GII HS archaed & 300 & & & - & - & - & - & 0.062 & - & 0.256 & 0.1354 & B & 10 \\
\hline Log prokaryote & 300 & & 1.409 & - & - & - & - & - & -0.249 & 0.490 & 0.0679 & $\mathrm{~B}$ & 12 \\
\hline Log leucine & 300 & & 2.804 & - & - & - & - & -0.143 & - & 0.391 & 0.1377 & $\mathrm{~B}$ & 11 \\
\hline Log GI HS ${ }_{1392}$ & $0,20,75$ & -0.080 & & -0.240 & & & 0.582 & -0.781 & - & 0.767 & $<0.0001$ & $\mathrm{~F}+\mathrm{B}$ & 124 \\
\hline GII HS archaed & $0,20,75$ & 0.019 & -0.265 & 0.031 & & & & & - & 0.207 & $<0.0001$ & B & 104 \\
\hline Log prokaryote & $0,20,75$ & 0.024 & & & 0.224 & & & - & 0.080 & 0.586 & $<0.0001$ & $\mathrm{~F}+\mathrm{B}$ & 70 \\
\hline Log leucine & $0,20,75$ & 0.085 & & 0.424 & 0.917 & & & & - & 0.762 & $<0.0001$ & $\mathrm{~F}+\mathrm{B}$ & 70 \\
\hline
\end{tabular}


ables in the model. Though significant, the measured variables at $75 \mathrm{~m}$ only accounted for 24.2 and $13 \%$ of the GI and GII HS variability respectively. When all the data $(0,20$ and $75 \mathrm{~m})$ were analyzed together, a substantial component of the archaeal GI signal (77\%) could be accounted for by a weak negative relationship with temperature, stronger negative relationship with chl $a$ and prokaryote abundance, as well as a strong positive relationship with $\mathrm{NO}_{2+3}-$. Positive relationships with temperature and $\mathrm{chl} a_{1}$ and a negative relationship with salinity explained $21 \%$ of the variability in the GII signal (when the 0,20, and $75 \mathrm{~m}$ data were pooled).

Analysis of the stepwise regression model for the prokaryote abundance and leucine incorporation data indicated that at times the model could account for the majority of the variability observed. The majority of the variability in the leucine incorporation data in surface waters $(60 \%)$ was due to a strong positive relationship with POC concentrations, a weak relationship with temperature, and a strong negative relationship with salinity. At $20 \mathrm{~m}$, the model did not explain the variance in the abundance data very well $\left(\mathrm{r}^{2}=0.07\right)$, yet the variables (chl a concentration, $\mathrm{C} / \mathrm{N}$ ratio and $\mathrm{POC}$ ) did account for the majority of the variance in the leucine incorporation rate $\left(\mathrm{r}^{2}=0.71\right)$. At $75 \mathrm{~m}, 36 \%$ of the variance in the abundance data could be explained with positive relationships with POC, salinity, and a weak relationship with temperature. Similarly, $34 \%$ of the variance in the leucine incorporation data was attributed to positive relationships with $\mathrm{POC}$, chl a, and a negative relationship with temperature. Deeper in the water column (150 m) the model did not explain the majority of the variance in either the prokaryote abundance or leucine incorporation rate data set. When data from the upper $75 \mathrm{~m}$ were combined the model accounted for 59 and $76 \%$ of the variance in the abundance and leucine incorporation rate respectively, where POC and chl a concentrations were clearly the most influential factors on the prokaryote community, with a smaller positive relationship with temperature.

\section{DISCUSSION}

Cultivation independent studies of natural prokaryotic assemblages employing DNA sequencing of small subunit rRNA genes have identified a variety of phylogenetically diverse, new marine prokaryotic groups (i.e. Giovannoni et al. 1990, Schmidt et al. 1991, DeLong 1992, Fuhrman et al. 1992, 1993, DeLong et al. 1993. Giovannoni et al. 1996, Gordon \& Giovannoni 1996, Field et al. 1997, Wright et al. 1997). However, little is known about the biology and ecology of many of these groups. In this study we have used rRNA tar- geted oligonucleotide hybridization experiments to monitor variability in picoplankton rRNA at several depths over a long-term (32 mo) period. Other biological, chemical, and physical oceanographic characters were sampled simultaneously so that the hybridization data could be interpreted in light of associated environmental conditions. This study focused on investigating the planktonic archaea, which have been detected in a variety of oceanic locations and environments including the SBC (DeLong 1992, Massana et al. 1997) and the nearby Southern California Bight (Fuhrman et al. 1992). The results of the present study indicate that the planktonic archaea are cosmopolitan residents of all coastal water masses sampled. Neither GI or GII planktonic archaea have been cultivated yet. Their physiology and ecological function are likely very different from their closest known phylogenetic relatives, the sulfur-dependent hyperthermophiles (GI) or the thermoplasmales (GII). This renders determination of their ecological roles speculative. Nevertheless their importance as a significant component of the picoplankton biomass is very evident from this and other studies.

Ribosomal rRNA hybridization proved to be a valuable means for monitoring long-term variability in the picoplanktonic assemblage. High replication and low variability in experimental correction factors for over 67 experiments indicated a reasonably high precision in the experimental protocol. These experiments are not subject to PCR amplification biases, since total rRNA was used as the target. However, the results are still subject to biases and variability in sample preparation, nucleic acid extraction and hybridization experiments. Interpretation is also limited by the calculation of relative rRNA abundances, rather than absolute values. This is also further complicated by the physiological variability of cellular rRNA content. Variations in rRNA could reflect changes in absolute cell numbers, physiological state, or a combination of both.

\section{Abundance and activity of the SBC prokaryotic assemblage}

Bacterioplankton abundances determined by enumerating DAPI-stained cells were generally consistent within a given depth and were similar to ranges reported for the Southern California Bight region (Geesey 1993). Peaks in prokaryote abundance occurred in January, May and September in different years and coincided roughly with or after periods of high chl a concentration or temperature increases. Overall, the relationship between bacterial abundance and chl a concentration was variable and deviated from described empirical relationships (Bird \& Kalff 
1984, Cole et al. 1988), though as described by McManus \& Peterson (1988), the relationships between bacteria and chlorophyll may hold on a large scale, but at smaller scales other factors are likely important.

The relationship between abundance versus activity has been used to infer relative importance of bottomup (nutrient limitation) and top-down (removal) processes (Billen et al. 1990), where slopes $>0.7$ are indicative of strong bottom-up control (Shiah \& Ducklow 1995) and slopes of 0.4 to 0.55 suggest moderate control by bottom-up processes (Dufour \& Torreton 1996). Linear regression between log prokaryote abundance and log leucine incorporation rate (Fig. 6A) indicated that prokaryotic abundance and activity were not directly coupled (slope $0.21, \mathrm{r}^{2}=0.53$ ). From this we can rule out control by bottom-up processes, and suggest that top-down processes such as grazing, sedimentation, or advection (which influence the relationship in a similar fashion) could be important factors in controlling the SBC prokaryote assemblages. Even though we did not measure all of the related parameters to discriminate between these different ecosystem regulation processes, this result is in agreement with Saunders et al. (1992), who demonstrated that topdown control processes were important in coastal and eutrophic environments, and bottom-up controls were more important in oligotrophic environments.

Most peaks in leucine incorporation rate were observed in April, May and at the end of September, and were found to correlate more significantly with chl a concentration and POC concentrations than for the prokaryote abundance data (Table 2b, Fig. 6). The linear regressions between log prokaryote abundance and $\log c h l$ a concentration indicated no relationship between absolute cellular abundances of prokaryotes and phytoplankton in this system (Fig. 6B). The linear regression between log leucine incorporation and log chl a concentration indicated a significant relationship (slope 0.86, $\mathrm{r}^{2}=0.55$, Fig. 6C). Similar relations have been described for estuarine (Hoch \& Kirchman 1993) and lake systems (Sommaruga \& Conde 1997). Also, unlike estuarine ecosystems which have been studied in recent years, where temperature was clearly the controlling environmental factor (Shiah \& Ducklow 1995, Goosen et al. 1997), prokaryote abundance in the SBC seemed to be independent of temperature control (though a peak in September did correlate with surface warming). Even though there was an $8^{\circ} \mathrm{C}$ spread in temperature at both the surface and $20 \mathrm{~m}$ through the annual cycle (12 to 20 or 10 to $18^{\circ} \mathrm{C}$, respectively), these temperatures may exceed the range for which this relationship holds $\left(<12^{\circ} \mathrm{C}\right.$, Hoch \& Kirchman 1993).

Several possibilities could account for the lack of relationship between the prokaryote abundance data and measured parameters. The absence of a relationship between chlorophyll concentration and bacterial abundance suggests that other factors such as allochthonous carbon (potentially advected with upwelled water masses), or other top-down controls could play important roles in controlling bacterioplankton

A.

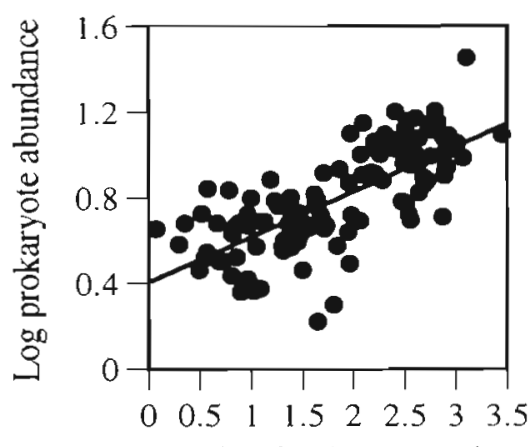

Log leucine incorporation

B.

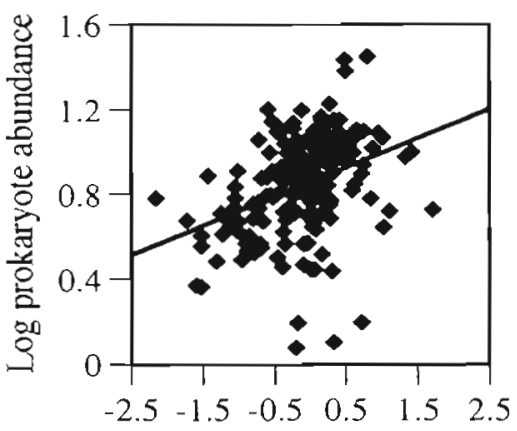

Log chlorophyll a concentration

C.

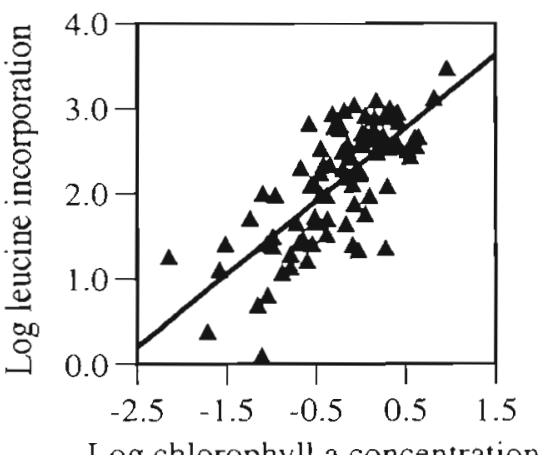

Log chlorophyll a concentration

Fig. 6. Log-log regressions of prokaryote abundance, leucine incorporation, and chl a concentration. (A) Relationship between log prokaryote abundance and log leucine incorporation. $y=0.21 x+0.41, r^{2}=0.53, n=120, p<0.0001$. (B) Relationship between log prokaryote abundance and log chl a concentration. $y=0.14 x+0.86, r^{2}=0.13, n=179, p<0.0001$ (C) Relationship between log leucine incorporation and $\log$ chlorophyll a concentration, $y=0.86 x+2.34, r^{2}=0.55$, $\mathrm{n}=86, \mathrm{p}<0.0001$ 
populations. DOC, which we did not determine, might have considerable influence on variability. One assumption often made regarding bacterioplankton assemblages is that as a whole they would react to environmental controls similarly. It is quite possible that there are independent controls affecting different groups of planktonic prokaryotes (Hollibaugh 1994). The factors influencing the SBC bacterioplankton assemblage are probably therefore the result of a combination of controls such as diurnal mixing (Shiah \& Ducklow 1995), substrate quality and quantity (ChinLeo \& Benner 1991), temperature (e.g. Shiah \& Ducklow 1995, Goosen et al. 1997), and top-down influences such as bacterivory (e.g. del Giorgio et al. 1996).

\section{Planktonic archaeal variability and ecology}

The planktonic archaea are a conspicuous member of the planktonic assemblage in the waters of the SBC. Lower archaeal rRNA relative abundances were detected in most surface water samples, although infrequent blooms exceeding $15 \% \mathrm{HS}_{1392}$ were observed on at least 7 occasions over the 32 mo period. Unlike the dramatic seasonal variation in rRNA abundance seen in the Antarctic surface waters (Murray et al. 1998), the pattern of archaeal rRNA abundance was not strongly seasonal in SBC surface waters. This long-term study extended and verified preliminary observations that members of the planktonic GI (Crenarchaeotea) and GII (Euryarchaeota) inhabit distinct depth zones in the water column and supports the concept that these 2 groups are governed by different environmental controls (Massana et al. 1997).

Vertical stratification in bacterioplankton groups defined by $16 \mathrm{~S}$ rDNA phylogenetic relationships appears to be a consistent feature of both the coastal and open ocean. Layering in the water column, the most important factor controlling primary production (Michaels et al. 1994), results in creating unique strata differentiated by chemical and physical conditions which partially define the biological community. As suggested by others (Giovannoni et al. 1996, Gordon \& Giovannoni 1996, Field et al. 1997, Wright et al. 1997) stratification in the water column appears to have led to specialization and selection of distinct phylogenetic groups adapted to specific regions of the water column, sometimes within highly related rDNA phylogenetic clusters (Field et al. 1997, Moore et al. 1998). In this study, the distributions of the 2 archaeal groups were overlapping but distinct.

The GII HS accounted for the majority of the archaeal HS in blooms detected at the surface and $20 \mathrm{~m}$. The GII HS did not correlate with upwelling conditions, or with upwelling water masses. GII blooms did not covary with chl a (Table 2) unlike other upper water column associated picoplankton (i.e. Chisholm et al. 1988, Gordon \& Giovannoni 1996), though some peaks in surface-associated GII rRNA (4/9) succeeded phytoplankton blooms ( $>2.5 \mathrm{\mu g} \mathrm{l}^{-1}$ chl a). Stepwise regression models with the environmental variables available did not explain the majority of the variability in the GII HS. Based upon the observation of higher archaeal signals in surface waters following periods of increased phytoplankton abundance, the GII archaea could be heterotrophs supported by DOC exudates from phytoplankton. However we cannot at present rule out possible photoautotrophic or photoheterotrophic modes of growth for GII archaea.

The GI archaea appear to be the predominant phylogenetic type foünd at $75 \mathrm{~m}$ dnd deeper in SBC waters. There was a moderate degree of variability in the archaeal $\mathrm{HS}_{1392}$ at 75,150 , and $300 \mathrm{~m}$ though the values rarely dropped below $20 \%$. When detected in surface waters, the GI signal correlated with upwelled water characteristics (low temperature, high salinity and density, and high nutrient concentrations), possibly indicating transport of these cells with the upwelled water. At $75 \mathrm{~m}$ and below, neither the measured environmental variables, nor correlations with water mass changes could explain the variability observed in the GI HS. Negative correlations with bacterial rRNA ( $\mathrm{r}=-0.44, \mathrm{p}=0.002)$, and a negative relationship with prokaryotic abundance in the stepwise regression model, suggested that the GI archaea were not dominant at times of high bacterial biomass or activity. This finding is consistent with other studies conducted in the Antarctic (Massana et al. 1998, Murray et al. 1998, 1999), where the GI archaea were only detected in appreciable amounts in surface waters during relatively low biomass and low productivity periods (austral winter). The correlation analysis indicated a positive relationship between the GI $\mathrm{HS}$ and $\mathrm{NO}_{2}{ }^{-}$ concentrations. Regressions for both the 20 and $75 \mathrm{~m}$ data were weak but significant $\left(\mathrm{r}^{2}=0.28, \mathrm{p}=0.017\right.$, $\mathrm{n}=20$, and $\mathrm{r}^{2}=0.22, \mathrm{p}=0.036, \mathrm{n}=20$, respectively). The subsurface maxima in nitrite was approximately at $40 \mathrm{~m}$ in the SBC. This finding is suggestive of a potential connection and suggests further avenues of investigation.

In combination with other reports (Fuhrman \& Davis 1997. Massana et al. 1997) it appears that the planktonic GI in temperate regions are consistently abundant in the subsurface (below the thermocline), suggesting specific adaptation to aphotic, inorganic nutrient rich, low temperature oceanic regions. Several lineages in the domain Bacteria have also been found to harbor similar subsurface distributions, suggesting the existence of a well-defined subsurface prokaryotic assemblage (Gordon \& Giovannoni 1996, Giovannoni et al. 
1996, Field et al, 1997, Wright et al. 1997, Murray et al. 1998). Inferring the ecological roles of uncultivated microorganisms, particularly those with no close cultivated phylogenetic relatives, will always be challenging. Detailed studies of their ecological distributions and variability will provide some of the necessary data to meet this challenge.

Acknowledgements. We are very grateful to all of our colleagues involved in the Santa Barbara Mooring project at the University of California, Santa Barbara. This project is the result of a collaborative effort from an interdisciplinary group of researchers at UCSB. Special thanks are extended to Chris Gottshalk, for excellent leadership in the field sampling aspect of this project. Appreciation is also extended to Libe Washburn for consultation on the hydrographic data. This work was supported by the Marine Science Institute and the Committee on Research, UCSB, and funded by National Science Foundation grant OCE 952984 to E.F.D

\section{LITERATURE CITED}

Amann RI, Binder BJ, Olson RJ, Chisholm SW, Devereux R Stahl DA (1990a) Combination of $16 \mathrm{~S}$ rRNA-targeted oligonucleotide probes with flow cytometry for analyzing mixed microbial populations. Appl Environ Microbiol 56 $1919-1925$

Amann RI, Krumholz L, Stahl DA (1990b) Fluorescentoligonucleotide probing of whole cells for determinative phylogenetic, and environmental studies in microbiology J Bacteriol 172:762-770

Azam F, Smith DC, Long RA, Steward GF (1995) Bacteria in oceanic carbon cycling as a molecular problem. In: Joint 1 (ed) Molecular ecology of aquatic microbes. NATO ASI Series, Vol G 38, Springer-Verlag, Berlin

Behl RJ, Kennett JP (1996) Brief interstatial events in the Santa Barbara basin, NE Pacific, during the past 60 kyr Nature (London) 379:243-246

Billen G, Servais P, Becquevort S (1990) Dynamics of bacterioplankton in oligotrophic and eutrophic aquatic environments: bottom-up or top-down control? Hydrobiologia $207: 37-42$

Bird DF, Kalff J(1984) Empirical relationships between bacterial abundance and chlorophyll concentration in fresh and marine waters. Can J Fish Aquat Sci 41:1015-1023

Campbell L, Vaulot D (1993) Photosynthetic picoplankton community structure in the subtropical North Pacific Ocean near Hawaii (station ALOHA). Deep-Sea Res I 40: 2043-2060

Chin-Leo G, Benner R (1991) Dynamics of bacterioplankton abundance and production in seagrass communities of a hypersaline lagoon. Mar Ecol Prog Ser 73:219-230

Chisholm SW, Olson RJ, Zettler ER, Goericke R, Waterbury JB, Welshmeyer NA (1988) A novel free-living prochlorophyte abundant in the oceanic euphotic zone. Nature (London) 334:340-343

Cho BC, Azam F (1988) Major role of bacteria in biogeochemical fluxes in the ocean's interior. Nature (London) 332: $441-443$

Cho BC, Azam F (1995) Urea decomposition by bacteria in the Southern California Bight and its implications for the mesopelagic nitrogen cycle. Mar Ecol Prog Ser 122:21-26
Cole JJ, Findlay S, Pace ML (1988) Bacterial production in fresh and saltwater ecosystems: a cross-system overview. Mar Ecol Prog Ser 43:1-10

del Giorgio PA, Gasol JM, Vaque D, Mura P, Augsti S, Duarte CM (1996) Bacterioplankton community structure: Protists control net production and the proportion of active bacteria in a coastal marine community. Limnol Oceanogr 41. $1169-1179$

DeLong EF (1992) Archaea in coastal marine environments Proc Natl Acad Sci USA 89:5685-5689

Delong EF, Franks DG. Alldredge AL (1993) Phylogenetic diversity of aggregate-attached vs, free-living marine bacterial assemblages. Limnol Oceanogr 38:924-934

DeLong EF, Wu KY, Prezelin BB, Jovine RVM (1994) High abundance of Archaea in Antarctic marine picoplankton. Nature (London) 371:695-697

DeLong EF, King LL, Massana R, Cittone $H$, Murray AE, Schleper C. Wakeham SG (1998) Dibiphytanyl ether lipids in nonthermophilic crenarchaeotes. Appl Environ Microbiol 64:1133-1138

Dufour PH, Torreton JP (1996) Bottom-up and top-down control of bacterioplankton from eutrophic to oligotrophic sites in the tropical northeastern Atlantic Ocean. DeepSea Res I 8:1305-1320

Field KG, Gordon D, Wright T, Rappé M, Urbach E, Vergin K, Giovannoni SJ (1997) Diversity and depth-specific distribution of SAR11 cluster rRNA genes from marine planktonic bacteria. Appl Environ Microbiol 63:63-70

Fuhrman JA, Azam F (1980) Bacterioplankton secondary production estimates for coastal waters of British Columbia, Antarctica, and California. Appl Environ Microbiol 39: $1085-1095$

Fuhrman JA, Azam F (1982) Thymidine incorporation as a measure of heterotrophic bacterioplankton production in marine surface waters: evaluation and field results. Mar Biol 66:109-120

Fuhrman JA, Davis AA (1997) Widespread archaea and novel bacteria from the deep sea as shown by 16 S rRNA gene sequences. Mar Ecol Prog Ser 150:275-285

Fuhrman JA, McCallum K, Davis AA (1992) Novel major archaebacterial group from marine plankton. Nature (London) 356:148-149

Fuhrman JA, McCallum K, Davis AA (1993) Phylogenetic diversity of subsurface marine microbial communities from the Atlantic and Pacific Oceans. App $\downarrow$ Environ Microbiol 59:1294-1302

Geesey GG (1993) Microbiology. In: Dailey MD, Reish DJ, Anderson JW (eds) Ecology of the Southern California Bight. University of California Press, Berkeley, p 190-232

Giovannoni SJ, DeLong EF, Olsen GJ, Pace NR (1988) Phylogenetic group-specific hybridization probes for identification of single microbial cells. J Bacteriol 170:720-726

Giovannoni SJ, Britschgi TB, Moyer CL, Field KC (1990) Genetic diversity in Sargasso Sea bacterioplankton. Nature (London) 345:60-63

Giovannoni SJ, Rappé MS, Vergin KL, Adair NL (1996) 16S rRNA genes reveal stratified open ocean bacterioplankton populations related to the green non-sulfur bacteria. Proc Natl Acad Sci USA 93:7979-7984

Goosen NK, van Rijswijk P, Kromkamp J, Peene J (1997) Regulation of annual variation in heterotrophic bacterial production in the Schelde estuary (SW Netherlands). Aquat Microb Ecol 12:223-232

Gordon DA, Giovannoni SJ (1996) Detection of stratified microbial populations related to Chlorobium and Fibrobacter species in the Atlantic and Pacific oceans. Appl Environ Microbiol 62:1171-1177 
Harms S, Winant CD (1998) Characteristic patterns of the circulation in the Santa Barbara Channel. J Geophys Res 103:3041-3065

Hayward TL (1996) Long-term change in the north pacific ocean: a consideration of some important issues. Cal COFI Rep, UCSD 37:41-44

Hendershott MC, Winant CD (1996) Surface circulation in the Santa Barbara Channel. Oceanography 9:114-121

Hoch MP, Kirchman DL (1993) Seasonal and inter-annual variability in bacterial production and biomass in a temperate estuary. Mar Ecol Prog Ser 98:283-295

Hollibaugh JT (1994) Relationship between thymidine metabolism, bacterioplankton community metabolic capabilities and sources of organic matter. Microb Ecol 28:117-131

Johnson KS, Petty RL, Thomsen J (1985) Flow injection analysis of seawater and micronutrients. In: Zirino A (ed) Mapping strategies in chemical oceanography. American Chemical Society, Washington, DC, p 7-30

Kirchman D, K'nees E, Hodson R(1985) Leucine incorporation and its potential as measure of protein synthesis by bacteria in natural aquatic systems. Appl Environ Microbiol 49: $599-607$

Lee S, Fuhrman JA (1990) DNA hybridization to compare species compositions of natural bacterioplankton assemblages. Appl Environ Microbiol 56:739-746

Lee S, Fuhrman JA (1991) Spatial and temporal variation of natural bacterioplankton assemblage studied by total genomic DNA cross-hybridization. Limnal Oceanogr 36: $1277-1287$

Massana R, Murray AE, Preston CM, DeLong EF (1997) Vertical distribution and phylogenetic characterization of marine planktonic Archaea in the Santa Barbara Channel. Appl Environ Microbiol 63:50-56

Massana $\mathrm{R}$, Taylor LT, Murray AE, Wu KY, Jeffrey WH, DeLong EF (1998) Distribution of marine planktonic archaea in the Gerlache strait, Antarctic Peninsula, during early spring. Limnol Oceanogr 43:607-617

McInerney JO, Mullarkey M, Wernecke ME, Powell R (1997) Phylogenetic analysis of group I marine archaeal rRNA sequences emphasizes the hidden diversity within the primary group Archaea. Proc R Soc Lond Ser B 264:1663-1669

McManus GB, Peterson WT (1988) Bacterioplankton production in the nearshore zone during upwelling off central Chile. Mar Ecol Prog Ser 43:11-17

Michaels AF and 11 others (1994) Seasonal patterns of ocean biogeochemistry at the U.S. JGOFS Bermuda Atlantic Time Series Study Site. Deep-Sea Res I 41: 1013-1038

Moore LR, Rocap G, Chisholm SW (1998) Physiology and molecular phylogeny of coexisting Prochlorococcus ecotypes. Nature (London) 393:464-467

Murray AE (1998) Bacterioplankton ecology: dynamics and variability in marine bacterial and archaeal assemblages, a molecular approach. PhD thesis, University of California, Santa Barbara

Murray AE, Preston CM, Massana R, Taylor LT, Blakis A, Wu KY, DeLong EF (1998) Seasonal and spatial variability of bacterial and archaeal assemblages in the coastal waters off Anvers Island, Antarctica. Appl Environ Microbiol 64: $2585-2595$

Murray AE, Wu KY, Moyer CL, Karl DM, DeLong EF (1999) Evidence for circumpolar distribution of planktonic A.rchaea in the Southern Ocean. Aquat Microb Ecol 18: $263-273$

Olson RJ, Chisholm SW, Zettler ER, Altabet MA, Dusenberry JA (1990) Spatial and temporal distributions of prochlorophyte picoplankton in the North Atlantic Ocean. DeepSea Res I 37:1033-1051
Pace NR, Stahl DA, DL Lane, Olsen GJ (1986) The analysis of natural microbial populations by rRNA sequences. Adv Microb Ecol 9:1-55

Parsons TR, Maita Y, Lalli CM (1984) A manual of chemical and biological methods for seawater analysis. Pergamon Press, New York

Paul JH, Myers B (1982) Fluorometric determination of DNA in aquatic microorganisms by use of Hoechst 33258. Appl Environ Microbiol 43:1393-1399

Polz MF, Cavanaugh CM (1997) A simple method for quantification of uncultured microorganisms in the environment based on in vitro transcription of $16 \mathrm{~S}$ rRNA. Appl Environ Microbiol 63:1028-1033

Porter KG, Feig YS (1980) The use of DAPI for identifying and counting aquatic microflora. Limnol Oceanogr 25:943-948

Preston CM (1998) Prokaryotic diversity in marine sponges. PhD thesis, University of California, Santa Barbara

Preston CM, Wu KY, Molinski TF, DeLong EF (1996) A psychrophilic crenarchaeon inhahits a marine sponge: Cenarchaeum symbiosum gen. nov., sp. Nov. Proc Natl Acad Sci USA 93:6241-6246

Raskin L, Stomley JM, Rittman BE, Stahl DA (1994) Groupspecific $16 \mathrm{~S}$ rRNA hybridization probes to describe natural communities of methanogens. Appl Environ Microbiol 60: $1232-1240$

Reimers CE, Lange CB, Tabak M, Bernhard JM (1990) Seasonal spillover and varve formation in the Santa Barbara Basin, California. Limnol Oceanogr 35:1577-1585

Saunders RW, Caron DA, Berninger UG (1992) Relationships between bacteria and heterotrophic nanoplankton in marine and fresh waters: an inter-ecosystem comparison. Mar Ecol Prog Ser 86:1-14

Schleper CS, Swanson RV, Mathur EJ, DeLong EF (1998a) Characterization of a DNA polymerase from the uncultivated psychrophilic archaeon Cenarchaeum symbiosum. J Bacteriol 179:7803-7811

Schleper CS, DeLong EF, Preston CM, Feldman FA, Wu KY, Swanson RV (1998b) Genomic analysis reveals chromosomal variation in natural populations of the uncultured psychrophilic archaeon, Cenarchaeum symbiosum. J Bacteriol 180:5003-5009

Schmidt TM, DeLong EF, Pace NR (1991) Analysis of a marine picoplankton community by $16 \mathrm{~S}$ rRNA gene cloning and sequencing. J Bacteriol 173:4371-4378

Sharp JH (1991) Total mass and particulate carbon, nitro gen and phosphorous. In: Hurd DC, Spencer DW (eds) Marine particles: analysis and characterization. Geophys Monogr 63:87-91

Shiah FK, Ducklow HW (1995) Multiscale variability in bacterioplankton abundance, production, and specific growth rate in a temperate salt-marsh tidal creek. Limnol Oceanogr 40:55-66

Simon M Azam F (1989) Protein content and protein synthesis rates of planktonic marine bacteria. Mar Ecol Prog Ser 51:201-213

Sommaruga $R$, Conde D (1997) Seasonal variability of metabolically active bacterioplankton in the euphotic zone of a hypertrophic lake. Aquat Microb Ecol 13:241-248

Stahl DA, Flesher B, Mansfield HR, Montgomery L (1988) Use of phylogenetically based hybridization probes for studies of ruminal microbial ecology. Appl Environ Microbiol 54: 1079-1084

Stein JL, Marsh TL, Wu KY, Shizuya H, DeLong EF (1996) Characterization of uncultivated prokaryotes: isolation. and analysis of a 40-kilobase-pair genome fragment from a planktonic marine archaeon. J Bacteriol 178:591-599

Voytek MA, Ward BB (1995) Detection of ammonium-oxidiz- 
ing bacteria of the beta-subclass of the Class Proteobacteria in aquatic samples with PCR. Appl Environ Microbiol $61: 1444-1450$

Waterbury JB, Watson SW, Valois FW, Franks DG (1986) Biological and ecological characterization of the marine unicellular cyanobacteriun Synechococcus. Can Bull Aquat Sci 214:71-120

Winant CD and 17 others (1996) Analysis and acquisition of observations of the circulation on the California continental shelf, La Jolla. Scripps Institution of Oceanography,

Editorial responsibility: David Karl,

Honolulu, Hawaii, USA
UCSD, Report no. 14-35-0001-30571, University of California, San Diego

Wright TD, Vergin KL, Boyd PW, Giovannoni SJ (1997) A novel delta-subdivision proteobacterial lineage from the lower ocean surface layer. Appl Environ Microbiol 63 1441-1448

Zheng D, Alm EW, Stahl DA, Raskin L (1996) Characterization of universal small-subunit rRNA hybridization probes for quantitative molecular microbial ecology studies. Appl Environ Microbiol 62:4504-4513

Submitted: January 8, 1999; Accepted: July 21, 1999 Proofs received from author(s): December 7, 1999 